\title{
Identification of candidate pelagic marine protected areas through a seabird seasonal-, multispecific- and extinction risk-based approach
}

Krüger $\mathrm{L}^{1,8 *}$, Ramos $\mathrm{JA}^{1}$, Xavier $\mathrm{JC}^{1,2}$, Grémillet $\mathrm{D}^{3,10}$, González-Solís $\mathrm{J}^{4}$, Kolbeinsson $\mathrm{Y}^{5}$, Militão $\mathrm{T}^{4}$, Navarro $\mathrm{J}^{3,6}$, Petry $\mathrm{MV}^{7,8}$, Phillips $\mathrm{RA}^{2}$, Ramírez $\mathrm{I}^{9}$, Reyes-González $\mathrm{JM}^{4}$, Ryan $\mathrm{PG}^{10}$, Sigurðsson $\mathrm{IA}^{11}$, Van Sebille $\mathrm{E}^{12}$, Wanless $\mathrm{RM}^{10,13}$, Paiva $\mathrm{VH}^{1}$.

${ }^{1}$ MARE - Marine and Environmental Science Centre, Department of Life Sciences, University of Coimbra, 3000-456 Coimbra, Portugal.

${ }^{2}$ British Antarctic Survey, Natural Environment Research Council, Cambridge UK.

${ }^{3}$ Centre d'Ecologie Fonctionnelle et Evolutive, UMR 5175, CNRS - Université de Montpellier Université Paul-Valéry Montpellier - EPHE, Montpellier, France.

${ }^{4}$ Department of Animal Biology and Biodiversity Research Institute (IRBio), Faculty of Biology, University of Barcelona, Spain.

${ }^{5}$ Northeast Iceland Nature Research Centre, Húsavík, Iceland.

${ }^{6}$ Conservation Biology Department, Estación Biológica de Doñana, Sevilla, Spain.

${ }^{7}$ Laboratório de Ornitologia e Animais Marinhos, Universidade do Vale do Rio dos Sinos, São Leopoldo, Brasil.

${ }^{8}$ Instituto Nacional de Ciência e Tecnologia Antártico de Pesquisas Ambientais INCT-APA, Brasil.

${ }^{9} \mathrm{Head}$ of Conservation for Europe and Central Asia, Birdlife International.

${ }^{10}$ Percy FitzPatrick Institute of African Ornithology, DST-NRF Centre of Excellence, University of Cape Town, Rondebosch, South Africa.

${ }^{11}$ South Iceland Nature Centre, Vestmannaeyjar, Iceland.

${ }^{12}$ Grantham Institute \& Department of Physics, Imperial College London, United Kingdom.

${ }^{13}$ Seabird Conservation Programme, BirdLife South Africa, Private Bag X5000, 2121, Johannesburg, South Africa

*Corresponding author:

Marine and Environmental Science Centre MARE, rua da Matemática, 49, Coimbra, Portugal, 3000-214

biokruger@gmail.com 
1 Abstract. With increasing pressure on the oceans from environmental change, there has been a

2 global call for improved protection of marine ecosystems through the implementation of Marine

3 Protected Areas (MPAs). Here, we used Species Distribution Modelling (SDM) of tracking data

4 from 14 seabird species to identify key marine areas in the southwest Atlantic Ocean, valuing

5 areas based on seabird species occurrence, seasonality and extinction risk. We also compared

6 overlaps between the outputs generated by the SDM and layers representing important human

7 threats (fishing intensity, ship density, plastic and oil pollution, ocean acidification), and

8 calculated loss in conservation value by using fishing and ship density as cost layers. The key

9 marine areas were located on the southern Patagonian Shelf, overlapping extensively with areas

10 of high fishing activity, and did not change seasonally, while seasonal areas were located off

11 south and southeast Brazil and overlapped with areas of high plastic pollution and ocean

12 acidification. Non-seasonal key areas were located off northeast Brazil on an area of high

13 biodiversity, and with relatively low human impacts. We found support for the use of seasonal

14 areas depending on the seabird assemblage used, because there was a loss in conservation value

15 for the seasonal compared to the non-seasonal approach when using 'cost' layers. Our approach,

16 accounting for seasonal changes in seabird assemblages and their risk of extinction, identified

17 additional candidate areas for incorporation in the network of pelagic MPAs.

18 Keywords: Ecologically and Biologically Significant Areas; Important Bird Areas; seabird tracking; species distribution modelling; threats; Zonation 
Oceans are facing rapid and profound changes in their characteristics and structure (Halpern et al., 2008; Rockström et al., 2009; Valdés et al., 2009). Ocean changes are so widespread that only $<4 \%$ of the global ocean area is considered to be experiencing very low human impacts (Halpern et al., 2015). Hence, there is a need for a major international effort to protect and maintain the functioning of marine ecosystems, through the implementation of Marine Protected Areas (MPAs) (Rockström et al., 2009; Kachelriess et al., 2014). Despite a global agreement to designate MPAs covering 10\% of the global ocean (Secretariat of the Convention on Biological Diversity, 2006), only $2.98 \%$ is currently protected, and $<1 \%$ of the global ocean comprise "notake' zones, where no harvesting of marine resources is allowed (Marine Conservation Institute 2015). Furthermore, few established MPAs effectively and integrally protect their targeted species, so their value is likely to be even lower than expected (Jameson, Tupper \& Ridley, 2002; Mora \& Sale, 2011; Edgar et al., 2014).

To truly protect the diversity of marine systems, the design of MPAs must account for its location (Jameson et al., 2002; Sundblad, Bergström \& Sandström, 2011), connectivity with other areas (Sundblad et al., 2011) number and proportion of protected oceanographic features (e.g. upwellings, seamounts; Sundblad et al., 2011; Dunn et al., 2014), species occurring there and their seasonality (Hyrenbach, Forney \& Dayton, 2000; Mann \& Lazier, 2006), climatic variability (Jameson et al., 2002), isolation from human impacts (Rife et al., 2013; Edgar et al., 2014), human activities (Charles \& Wilson, 2009; Edgar et al., 2014; Mazor et al., 2014) and, socio-economic use of the area (Charles \& Wilson, 2009). Most MPAs are designed to improve fisheries management, i.e. to manage commercial fish stocks in a more sustainable way (e.g. (Pitchford, Codling \& Psarra, 2007; Horta e Costa et al., 2013ab; Stevenson, Tissot \& Walsh, 2013). Few studies have accounted for other environmental factors in the design of MPAs. For instance, ship movements (Dalton, 2004; Halpern et al., 2008), exposure to plastics (Lebreton, Greer \& Borrero, 2012; van Sebille, England \& Froyland, 2012; Wilcox, Van Sebille \& 

impacts to marine biodiversity, and should be considered in MPA design (Kelleher, 1999; Pomeroy et al., 2005).

Wide-ranging, pelagic top predators have been widely proposed as useful tools for pointing out important areas which can add conservation value to MPA networks (Hooker \& Gerber, 2004; Sergio et al., 2008; Ronconi et al., 2012). Top-predators integrate factors affecting seasonal variation in abundance and distribution of their lower trophic-level prey over broad areas (Montevecchi et al., 2012; Tancell et al., 2012; Michael, Jahncke \& Hyrenbach, 2014). Seabirds, in this context, are relatively easy to sample at their breeding colonies and to track them at sea by using electronic devices, providing information on foraging movements at various spatio-temporal scales (Phillips et al., 2006a; Delord et al., 2014; Thiebot et al., 2014). Several important marine areas have been identified based on the distribution and occurrence of seabird species and proposed to integrate the current network of MPAs. The marine Important Bird Areas (mIBAs) represent one of the most recent wide-ranging international efforts to identify relevant areas for marine conservation (Lascelles et al., 2012, 2016).

Here, we applied spatial distribution modelling to tracking data from 14 pelagic seabird species in the southwest Atlantic Ocean (Food and Agriculture Organization, FAO, Fishing Area 41). The use of tracking data is deliberately used to identify important areas in offshore waters since many important "coastal" areas have been identified for MPAs or MIBAs through other approaches and investigations of coastal seabirds. We identified key areas based solely on the climatic and oceanographic variables irrespective of the distribution of threats, a posteriori we quantified sensitivity of species to threats and quantified the costs to human activities within those areas that are important for the birds, by imposing restrictions of activities within the areas and calculating changes in conservation value. Such approach is justified by evidences that the distribution of threats matches oceanographic conditions targeted by marine animals (Karpouzi, Watson \& Pauly, 2007; Hatch et al., 2008; Titmus \& Hyrenbach, 2011; Krüger et al., 2016a). 
quantify the sensitivity of the identified important areas for seabird assemblages to environmental pressures; (3) compare our spatially-explicit results to the existing networks of proposed or established protected areas identified by international organizations, and (4) carry out a cost analysis evaluation of the implementation of seasonal vs non-seasonal protected areas. FAO Fishing Area 41 encompasses a wide range of latitudes from tropical to Antarctic waters, including a large array of habitats and oceanographic conditions, the largest continental shelf in the Southern Hemisphere and a highly productive convergence zone that support a biodiversityrich ecosystem, and major fisheries (Vasconcellos \& Csirke, 2011). Despite several proposals to identify key areas for conservation in pelagic ecosystems, either in the form of Ecologically and Biologically Significant Areas (EBSAs) (Dunn et al., 2014) or mIBAs (Lascelles et al., 2012), the designated MPAs inside FAO41 are mostly restricted to coastal regions (Marine Conservation Institute 2015, http://www.mpatlas.org/explore/). Thus, such network of MPAs does not protect marine pelagic species and systems. In this sense, our analysis prioritizes habitats used by pelagic seabird communities weighted by their seasonality and extinction risk (which may protect other pelagic species) as pelagic habitats are underrepresented in the MPAs network within FAO41. The key areas identified with this study may be seen as supporting the already proposed MPAs as add-ons, which indentifies pelagic and seasonal areas that were not considered by previous methods.

\section{Materials and methods}

\section{Tracking data and bird assemblages}

We used geolocator (Global Location Sensor or GLS) tracking data from 14 seabird species, occurring at the southwest Atlantic Ocean during part or all of the annual cycle (Table 1). Deployment and other details are provided elsewhere (Grémillet et al., 2000; Croxall et al., 2005; Phillips et al., 2006a; González-Solís, Croxall \& Afanasyev, 2008; González-Solís et al., 2009; Mackley et al., 2010; Quillfeldt et al., 2013; Ramírez et al., 2013; Reid et al., 2013; Missagia et al., 2015, Krüger et al., 2016a,b). The data were modelled in three different periods: summer (Oct.-Mar.), winter (Apr.-Sep.) and year-round (Jan.-Dec.). For summer and winter 
periods, we removed bird locations from months when the number of points was below $10 \%$ of

102 the maximum number for that species in any month in order to remove the interference of migratory movements from the seasonal data, but all available locations were included in the year-round models. Each species was classified as one of two groups, based on its core distribution relative to the mean position of the northern boundary of the Subtropical Front (Burls \& Reason, 2006): Southern species (i.e. species with a distribution largely south of $35^{\circ} \mathrm{S}$ within the area) and Northern species (i.e. species mainly distributed north of $35^{\circ} \mathrm{S}$ within the area). This categorisation was based on previous evidence for segregation of seabird communities resulting mostly from latitudinal gradients in sea surface temperature (Péron et al., 2010; Krüger \& Petry, 2011; Navarro et al., 2015; Quillfeldt et al., 2015).

\section{Environmental variables}

Our Species Distribution Models (SDMs) used 10-year average data (from summer, winter and year-round) for the following oceanographic variables: chlorophyll-a concentration (CHL), CHL anomaly, CHL gradients, sea surface temperature (SST), SST anomaly, SST gradients, Sea Surface Height (SSH), SSH anomaly, wind speed, water depth, and minimum distance to coast (DCOA) (Supporting Information Fig. S1). All variables, except DCOA, anomalies and gradients, were downloaded as monthly mean composite raster images from NOAA CoastWatch Browser (http://coastwatch.pfeg.noaa.gov/). SST anomalies and CHL anomalies for each month were calculated as the difference between the average value for a given month and year, and the average for that month over a 10-year period in that grid cell. Gradients were generated by calculating the standard deviation of each cell in relation to the adjacent cell values (Sidhu et al., 2012; Li et al., 2015). All raster files were processed in ArcMap 10.2.

124 Tracking data was combined with environmental predictors to generate SDMs from presenceonly data using the Maximum Entropy (MaxEnt) software (Oppel et al., 2012; Quillfeldt et al., 2013) on a $1^{\circ} \times 1^{\circ}$ spatial grid (e.g. Pinet et al., 2011; Ramírez et al., 2013; Missagia et al., 2015), as the mean error of geolocation tags is usually lower than $1^{\circ}$ (Wilson et al., 1992; Phillips et 
al., 2004; Nielsen \& Sibert, 2007). Geolocators are useful to detect and model core areas for animals' distribution (Quillfeldt et al., 2013; Krüger et al., 2016a, 2016b) and compared to more accurate methods like GPS or Argos, geolocators tend to slightly inflate home range of animals (Phillips et al., 2004). To compensate this potential inflation, we were conservative in the next steps of the analysis by only assuming areas of high importance values (see next section) to propose the key areas. Furthermore, geolocators are able to collect data for a longer period of time that is highly limited by battery size in GPS and PTTs, and this may also represent a barrier to sample distribution data on smaller seabirds like gadfly petrels and prions which can not carry much weight. The tracking data were divided into training and test data by randomly setting aside $10 \%$ of the tracking dataset for spatial evaluation of the models (Araújo \& Guisan, 2006; Austin, 2007). The first step of the modelling consisted of principal component analyses (PCA) to eliminate any potential effect of multicollinearity. This is a recommended procedure as our goal was to model species distributions, rather than to verify relationships between species occurrence and the environment (Merow, Smith \& Silander, 2013). We extracted the scores for components with eigenvalues above 1. With those scores, we ran MaxEnt on the presence-only positions, 50 times, with a bootstrap procedure to obtain a prediction of the average distribution (Edrén et al., 2010). We assessed the accuracy of models using the area (AUC) under the Receiver Operating Characteristic (ROC) curve. The AUC estimates the likelihood that a randomly selected presence point is located in a raster cell with a higher probability value for species occurrence than a randomly generated point (Phillips, Anderson \& Schapire, 2006).

\section{Calculating area importance values}

The outputs from MaxEnt were used to calculate area importance values for each bird assemblage using the Zonation software (Moilanen et al., 2005; Moilanen \& Wintle, 2006; Leathwick et al., 2008). Zonation is assumed as one of the best programs to set out conservation priorities when efforts focus on ecological communities and habitat connectivity (i.e., Blumentrath, 2011; Delavenne et al., 2012). Zonation generates a raster with pixels representing 
the importance value, taking into account the probability of occurrence of each species given its weighting (see below) and response to habitat. The final output is scaled from $0-1$, representing the least (0) to most important (1) areas. Each species was weighted by its IUCN conservation status as follows: Least Concern $(\mathrm{LC})=1$; Near Threatened $(\mathrm{NT})=2$; Vulnerable $(\mathrm{VU})=3$; Endangered $(E N)=4$ and Critically endangered $(C R)=5$. Boundary Quality Penalty Curves (BQPCs; Moilanen \& Wintle, 2007), which are measures of species responses to habitat connection, were constructed empirically based on the IUCN conservation status. We generated responses with changing slopes for $\mathrm{CR}=-0.01, \mathrm{EN}=-0.008, \mathrm{VU}=-0.004, \mathrm{NT}=-0.002$ and $\mathrm{LC}$ $=0$. Thus, the proportion of area occupied by each species decreases with increasing habitat disconnection (except for LC) and the intensity of the decrease (slope) is proportional to the level of threat.

We evaluated the sensitivity of the weighting and habitat connectivity response (more details in Supporting Information SI). Changing the values for these two variables had no substantial effect on the final output, except for a complete null model considering all species as equivalent, the output from which was unrealistic and did not match the species distributions (Supporting Information Fig. S2, S3, S4). Probability of occurrence in a given pixel diminishes when habitat characteristics differ from those within surrounding cells, using a home rangebased grid size (Leathwick et al., 2008). Uncertainty analysis (Moilanen \& Wintle, 2006) was disabled in the computation (Leathwick et al., 2008). The importance value was calculated for each assemblage during the three specified periods (summer, winter and year-round). We were conservative to propose key areas due geolocators errors (see previous section) and selected areas that fell within $1 \%$ (90\% of importance value) of the distribution threshold (Moilanen et al., 2005), areas of $0.5 \%(95 \%)$ and $0.1 \%(99 \%)$ threshold (Oppel et al., 2012), in a nested design - these areas are within the $1 \%$ threshold. The locations of the $0.1 \%$ candidate MPAs were compared with those of existing MPAs (Marine Conservation Institute 2015), EBSAs (Dunn et al., 2014) and mIBAs (Birdlife International 2015).

\section{Environmental threats}


182 We examined spatial risk from five environmental threats: ocean acidification, oil pollution,

183 floating plastics, shipping and fishing intensity (Supporting Information SII, Fig.S5), which are environmental stressors largely recognized as stressors to which marine animals, particularly seabirds, are exposed and vulnerable, by means of spatial overlap and evidence of impact: acidification (Grémillet \& Boulinier, 2009), oil pollution (Camphuysen \& Heubeck, 2001; Wiese \& Robertson, 2004; Moreno et al., 2013), plastic (Titmus \& Hyrenbach, 2011; Jiménez et al., 2015; Wilcox et al., 2015), shipping (Hatch et al., 2008), fisheries (Anderson et al., 2011; Croxall et al., 2012). These variables were standardized to have a mean of 0 and an SD of 1 (Zuur, Ieno \& Smith, 2007).

\section{Cost analysis}

192

We evaluated costs for the proposed key areas, using the layers from Fishing Vessels Density and overall Ship Density (Supporting Information SII and Fig. S5) as cost layers (Dalton, 2004; Leathwick et al., 2008) in the Zonation software. We are using those layers as 'costs' because both are the most manageable factors from the most widespread human threats affecting marine fauna worldwide. Impact of fisheries on marine fauna are well described in literature, like food depletion through overfishing and direct mortality through bycatch (Becker \& Beissinger, 2006; Cury et al., 2011) but the vessel traffic is a potential source of oil (Halpern et al., 2008, 2015; Hatch et al., 2008) and noise (Morton \& Symonds, 2002; Weilgart, 2007; Codarin et al., 2009) pollution, and birds may collide against vessels during the night (Black, 2005; Glass \& Ryan, 2013).

Zonation uses cost layers to reduce the value (importance to conservation based on the previously specified parameters) of a given cell, thus cost is interpreted as a variable that reduce the conservation value of a given area. The "cost" variables were used here as a cost/limitation imposed to human activities, in the perspective that a no-cost represent no changes in the current activities, and a cost represent restrictions to activities. As our valuing of areas considers no influence of the human activities, sole the seabirds distribution regarding environmental variables, this represents the hypothetical value of the area under no constraint by human 
activities. Then it is possible to measure differences on the conservation value of an area when comparing different cost scenarios with the previous area valued under no influence of human activities. We used two cost constraint scenarios to evaluate how the intensity of human activities may change the conservation value of candidate MPAs (i.e. key marine areas) if shipping and fishing were not regulated (no-cost, scenario 1) or partially regulated (cost, scenario 2). Costs constraints were calculated to each time-frame (Summer, Winter and Yearround). The resulting values for each cost model were then subtracted from the respective area importance value within the 99, 95 and 90 threshold values (the proposed areas based on seabird distribution only), to evaluate how much each of the human activities change the conservation values within the proposed key areas.

\section{Statistical Analysis}

We used the pixel value of the rasters as point information, and the centroid of longitude and latitude ( $\mathrm{N}=1697)$ as the geographic position of each grid cell. To evaluate the degree of correspondence between the distribution probabilities for the two seabird communities (MaxEnt outputs) and the distributions of the environmental threats, we used Canonical Correspondence Analysis (CCA) using 'cca' function from the 'vegan' package (Oksanen et al., 2013) within the R environment (R Core Team 2015). Species probabilities were arcsine transformed. Species matrix entered the analysis as dependent matrix, and the threats entered the analysis as the independent matrix, with geographical coordinates used as covariables to control for spatial auto-correlation (cca[Species Matrix $\sim$ Threat Matrix + Latitude * Longitude]). Each time-frame was analyzed in separate. After running the analysis, we quantified the Euclidian distance of the species from the threats in the CCA bi-dimensional space to compare shifts in group exposition to threats.

We compared the change of value within the proposed key areas between cost models, time-frames and assemblages through a Generalized Linear Mixed Model in 'Ime4' package within R-environment (Bates et al., 2015). As threshold values for proposed key areas $(90 \%$, 
$95 \%$ and $99 \%$ of importance values) are in a nested design, we entered the threshold as a random factor in the model.

\section{Results}

\section{Species Distribution Models}

Many of the environmental variables were highly correlated (Supporting Information Table S1).

The power of the models using PC1 and PC2 to predict species distribution was high (AUC $=0.79 \pm 0.06$ ), although the models were less accurate for species with large latitudinal ranges, such as Cory's Shearwater (Calonectris borealis), Cape Verde Shearwater (Calonectris edwardsii), Great Shearwater (Ardenna gravis) and Wandering Albatross (Diomedea exulans). It was clear that dividing the data into two seasons resulted in a slightly more accurate prediction of distributions than using data from the entire year (AUC summer $=0.80 \pm 0.06$; AUC winter $=0.83 \pm 0.05$; AUC year-round $=0.76 \pm 0.06$ ), probably because species occupy only part of the annual distribution in any one season (Fig. S6, S7, S8).

\section{Assemblages and Environmental Change Factors}

Canonical Correspondence Analysis yielded slight different results for each time frame, for Summer the constrained analysis captured $74.1 \%$ of data variability (axis $1=83.0 \%$, axis $2=$ $12.3 \%), 70.7 \%$ for Winter (axis $1=81.9 \%$, axis $2=15.9 \%$ ) and $77.2 \%$ for all Year $($ axis $1=$ $81.9 \%$, axis $2=14.9 \%$ ). Probability of occurrence of species (species matrices) was significantly matched by the distribution of threats for Summer $\left(\mathrm{F}_{8,1638}=585.49, \mathrm{P}=0.001\right)$, Winter $\left(\mathrm{F}_{8,1638}=\right.$ 494.48, $\mathrm{P}=0.001)$ and all $\mathrm{Year}\left(\mathrm{F}_{8,1638}=691.34, \mathrm{P}=0.001\right)$.

There was a clear segregation between assemblages within the bi-dimensional space of the CCA which showed that Northern species were more exposed with plastic pollution and acidification, while Southern species were associated with Fisheries and Ship Traffic (Fig. 1a,b,c). However, such trend was not obvious in Winter (Fig.1b) as the two Northern species (TA and TP) were highly pelagic and occurred in areas of low cumulative threat occurrence (see Supporting Information Fig. S5, Fig. S7). In Winter two sub-groups of Southern seabirds were 

(MS and WCP) which seem to be caused by their wide latitudinal distribution. This was reflected in the bi-dimensional distance of each group from threats, where Northern seabirds increased their distance from threats in Winter comparing to Summer and all Year, but Southern seabirds decreased their distance from threats in Winter comparing to Summer and all Year, with exception of WCP (Fig. 1d-i).

\section{Proposed key marine areas}

The areas of highest value for Southern species did not vary seasonally, and were off the southern tip of South America and near the Falkland Islands (Fig.2). In contrast, results for Northern species were highly seasonal: a) during summer, the highest value areas were off the central coast of Brazil, whereas in the winter, these extended to oceanic waters in the mid-south Atlantic, b) considering the whole year, the highest value areas were coastal and pelagic waters off northern Brazil (Fig.2). The zonation value increased with the species occurrence probability (Fig. 3a,c,e) and with increased number of species (Fig. 3b,d,f). It means the high valued areas are a good representation for the occurrence of species.

The candidate protected areas based on the Southern assemblage were concentrated in the same area during summer, winter and year-round (Fig.4). The three temperate areas were located south of Isla de los Estados and northwest of the Yaghan Basin. The candidate MPAs for Southern seabirds overlapped in the north with the current Isla de los Estados MPA (Argentinean Ecological and Provincial Reserve) and IBA (proposed to protect BBA and Sooty Shearwater Ardenna grisea) and in the south with Southwest 33 IBA (proposed for GHA), but most areas of high value for Southern seabirds lacked any protection under current regimes (Fig.4). On the other hand, the candidate protected areas for Northern seabirds were completely different among time-frames. The candidate summer area on North overlapped with part of the proposed EBSA off southern Brazil (proposed due to occurrence of a strong upwelling) and the 

fraction of a designated MPA overlapped the key area identified for Northern seabirds in the summer: the Litoral Centro Environmental Protection Area. During winter, the key area for Northern seabirds was in pelagic waters, over the gyre northeast of the Rio Grande Rise, where there is a large elevation of the seabed. Currently no EBSA or IBA has been proposed in this region. Finally, the year-round key area for Northern seabirds was on the shelf slope and pelagic waters off northern Brazil, reaching as far as an oceanic ridge, where there is a strong upwelling from the Amazon River (Fig.4). Roughly, one-third of this area overlapped with the Amazonian-Orinoco EBSA, proposed due to the enhanced marine productivity occurring within this area (Fig.4). The overlap of our proposed key areas with existing MPAs was minimal (less than $1 \%$ Table 2). The percentage of mIBAs and EBSAs overlapped by our key areas was also minimal, however overlap of Northern areas with EBSAs was substantially greater than Southern areas, while Southern Areas were more overlapped by proposed mIBAs than Northern areas (Table 2).

\section{Cost analysis}

The use of cost constraints for Southern seabirds resulted in few spatial differences of values when using Fishing Density as a cost layer, but higher conservation values in pelagic areas shifted north when using Ship Density as a cost layer (Supporting Information Fig. S9). On the other hand, using Fishing Density as a cost layer for Northern seabirds displaced the zones of high values to spread south, and to spread to pelagic areas when Ship Density was the cost layer (Supporting Information Fig. S10). 4143.9, $\mathrm{P}<0.001)$. The higher changes in values for Southern occurred when we used Fishing Density as a cost layer during summer, for both No Cost and Cost models, for winter when using Ship Density No Cost model and for year when using Ship Density Cost model (Fig.5,

313 Supporting Information Table S2). On the other hand, the change in values for Northern were 314 higher for year-round for both No Cost and Cost models and for both Fishing and Ship Density 
cost layer, despite using Ship Density there was also a high change of value during summer for both cost models (Fig.5, Supporting Information Table S2).

\section{Discussion}

In our study, we considered a modelling approach that distinguishes between ecological groups and accounts for seasonality in distribution of pelagic seabirds, with a view to identify a more representative network of key sites that would be more effective year-round MPAS. This approach located areas where currently there are few designated or proposed MPAs, suggesting that a community integrated approach can be an effective way to propose new pelagic MPAs (Yorio, 2009; Ronconi et al., 2012; Thaxter et al., 2012) in addition to proposals which use one or few attributes of one area, such as the presence of seamounts, reefs, or the occurrence of one focal species (Arcos et al., 2012; Grecian et al., 2012; Dunn et al., 2014).

\section{High Valued Areas, Threats and Benefits}

We placed the most important area for Southern seabird species within the southwest Atlantic at the southern Argentina shelf slope, and around the Falkland Islands. This area has long been recognized as important for marine predators and conservation of biodiversity (Croxall \& Wood, 2002). This is reflected in the large number of proposed BirdLife International mIBAs (BirdLife International 2015), and several designated coastal MPAs, including the large reserves of Namuncurá and Isla de losEstados (Argentine National Parks; Marine Conservation Institute 2015). These waters are used by several and abundant seabird species during the breeding and non-breeding seasons, including birds from Patagonia (Yorio et al., 1999; Yorio, 2009), Falkland Islands (Grémillet et al., 2000; White et al., 2002), South Georgia (Croxall \& Wood, 2002; Croxall et al., 2005; Phillips et al., 2006a; Navarro et al., 2015), Tristan da Cunha and Gough (Ronconi, Ryan \& Ropert-Coudert, 2010; Reid et al., 2013), and New Zealand (Nicholls et al., 2002). Marine mammals also rely on this area during part of the year, including Fin (Balaenoptera physalus), Sei (B. borealis), Minke (B. acutorostrata), Sperm (Physester macrocephalus), Southern Bottlenose (Hyperoodon planifrons) and Long-finned Pilot (Globicephala melas) whales, Hourglass (Lagenorhynchus cruciger), Peale's (L. australis) and 

for marine top predators results from the extensive, year-round upwelling that extends from subAntarctic to temperate waters, which supports a rich food web, including diverse communities of abundant squid and fishes (Acha et al., 2004; Miloslavich et al., 2011). As a consequence of such rich communities, both fishing vessels and seabirds target those areas (Grémillet et al., 2000, 2008; Wakefield, Phillips \& Belchier, 2012). In fact we found a higher "exposition" of seabird to fisheries, which is well-known for the study area (Xavier et al., 2004; Bugoni et al., 2008; Jiménez et al., 2010, Krüger et al., 2016a), and elsewhere (Anderson et al., 2011; Lewison et al., 2014). In the other hand, the vessel traffic is a potential source of threat for marine fauna, by oil (Halpern et al., 2008, 2015; Hatch et al., 2008) and noise (Morton \& Symonds, 2002; Weilgart, 2007; Codarin et al., 2009) pollution. Northern seabird species, which reflects the seasonality of species present in the area throughout the year. This is mostly a consequence of migratory species such as Deserta's Petrel, Trindade Petrel and Cory's Shearwater. It also reflects the different types of habitats targeted by these species. The highly valued area during summer supports a highly diverse coastal ecosystem, including corals reefs (Roberts et al., 2002) and mangroves (Polidoro et al., 2010), and a relatively narrow shelf with several seamounts (Miloslavich et al., 2011), supporting several taxa, particularly sharks, cetaceans and euphausiids (Tittensor et al., 2010), and is intensively used by the species in this study, as evidenced by other authors (Dias et al., 2011; Catry et al., 2013; Dias, Granadeiro \& Catry, 2013; Ramírez et al., 2013; Missagia et al., 2015; Krüger et al., 2016a). During winter, the most important areas matched with an area of low biodiversity (Tittensor et al., 2010) and low productivity near the South Atlantic tropical gyre. Short-term decreases in chlorophyll concentration within gyres due to climate shifts are a potential issue of concern, with implications for management (Gregg, Casey \& McClain, 2005; Polovina, Howell 
distribution of the Critically Endangered Tristan Albatross (Reid et al., 2013), and the at-sea distribution during the breeding season and immediate post-breeding period of the Vulnerable Trindade Petrel (Krüger et al., 2016b). The important areas year-round matched the upwelling where the Amazon and Orinoco river plumes reach seamounts and islands, such as Fernando de Noronha and São Pedro and São Paulo (Kitchingman et al., 2008; Miloslavich et al., 2011). It is important to emphasize that the high valued (99\%) year-round areas reflected more the suitable habitat for the species than the bulk of species distribution (i.e. Gonzáles-Solís et al., 2009, Ramírez et al., 2013, 2015), despite the lower values (0.90) embraced those areas presented by those authors. However the $99 \%$ valued area is recognized as biologically important for the intense upwelling, which supports a biodiverse ecosystem (Tittensor et al., 2010; Miloslavich et al., 2011; Selig et al., 2014), so highliting the value of this area for conservation, which is used less frequently by the seabird species in this study

Many of our study species ingest large amounts of plastic debris (Petry \& Fonseca, 2002; Jiménez et al., 2015), and the sensitivity of the Northern species to Plastic pollution evidences that. The drifting model used in this study (Van Sebille et al., 2012) assumes that plastic particles are carried by currents and accumulate in zones of lower current speed, mainly gyres (Van Sebille, 2015). Titmus \& David Hyrenbach (2011) found that some seabird species target those same areas of plastic concentration, because they tend to be characterised by a high occurrence of squid and flying fish (Titmus \& Hyrenbach, 2011; Wilcox et al., 2015). Our results provide circumstantial supporting evidence, but highlight the need for more studies to evaluate the overlap of seabird distribution with floating plastics, and the associated risk. Similarly, direct evaluations of the effects and implications of spatial variation in rates of ocean acidification for seabirds are lacking. Acidification is linked to enhanced levels of $\mathrm{CO}_{2}$ in the atmosphere released by human activities (Cao \& Caldeira, 2008). Severe decreases in pH may affect lower trophic levels in food webs (Cao \& Caldeira, 2008; Pörtner \& Peck, 2010; Hale et al., 2011), with consequent impacts on top predators (Grémillet \& Boulinier, 2009). 

previous efforts to define both EBSAs (Dunn et al., 2014) and BirdLife International mIBAs (Lascelles et al., 2012; Ronconi et al., 2012), although in other respects there was some overlap. As the currently designated MPAs are all coastal (Marine Conservation Institute 2015), our analyses of tracking data from pelagic seabirds showed almost no overlap with areas that are presently protected by national legislation.

\section{Potential Costs}

We found an assemblage and time-frame differential change in costs that suggests that the use of seasonal protected areas could mean less impact on human activities to achieve high conservation value as proposed by Hyrenbach, Forney \& Dayton (2000). For instance, by changing the fishing density by half, the changes for values within the key Southern areas did not change substantially in relation to the no-cost model. On the other hand, for Northern areas, the changes in value were relatively higher when applying cost layers, and for all the cost models the non-seasonal approach always resulted in a higher change in values. That's probably a result of the higher seasonality for the species occurrence in the northern areas, whereas the occurrence of species in the south off Patagonia and subantarctic waters is more constant throughout the year. Leathwick et al. (2008) also showed that changes in conservation value of an area compared between models with and without use of cost layers can vary from $5 \%$ to $10 \%$, but in our case the mean differences could reach as high as $50 \%$ for Northern seabirds.

\section{Conclusions}

415 By assigning seabirds to different assemblages, we were able to detect additional candidate areas for protection not recognised in previous marine spatial planning initiatives for FAO Region 41 in the southwest Atlantic Ocean. Hence, our results help guiding conservation 418 decisions at both national and international levels, in terms of potential new MPAs and 419 implementation of those already designated or proposed as EBSAs or mIBAs. Our analysis support the network of areas proposed as mIBAs in sub-Antarctic waters; the ultimate goal of

421 BirdLife International is that these areas receive statutory protection (BirdLife International 
2015). We also call attention for the need to delineate protected areas in pelagic tropical waters

423

both within the Brazilian EEZ, and in international waters. Those unprotected regions are important seasonally or year-round, and are subject to a wide array of Human-related threats.

While in most cases the establishment of MPAs is aimed at improving management of fishing activities (Pitchford et al., 2007; Stevenson et al., 2013) several other factors may threaten species and ecosystems. Human activities, such as fishing, ship traffic and oiling, may be controllable to a large extent if there is a means of enforcing compliance with effective management regimes, but other threats associated with dynamic features of natural systems, such as ocean acidification and plastic pollution, present considerable challenges in the design and implementation of MPA networks (Conroy et al., 2011).

The application of our approach to other oceans should reveal new areas to be incorporated in conservation networks. The benefits elsewhere would be highly dependent on the degree of seasonality in predator distributions, but it seems likely there are parallel situations where areas are only used for part of the year by migratory species. We envisage that this technique can be used on finer temporal (e.g. incubating versus chick rearing periods) and spatial (e.g. by the use of GPS or PTT devices) scales.

\section{Acknowledgments}

L.K. acknowledges the Brazilian National Council of Technological and Scientific Development $\mathrm{CNPq}$ for his $\mathrm{PhD}$ scholarship (Programa Ciência sem Fronteiras processo 245540/2012-1). T.M. and V.H.P. acknowledge the doctoral and post-doctoral grants (respectively) given by 'Fundação para a Ciência e Tecnologia' (SFRH/BD/47467/2008 and SFRH/BPD/85024/2012) and the Biodiversity Research Institute (IRBio). J.C.X. was supported by the Investigator FCT program (IF/00616/2013). J.M.R.-G. was supported by Formación de Profesorado Universitario PhD grants programme (FPU; AP2009-2163). J.N. was supported by the Andalucía Talent Hub Program launched by the Andalusian Knowledge Agency, co-funded by the European Union's Seventh Framework Program, Marie Skłodowska-Curie actions and the Ministry of Economy, Innovation, Science and Employment of the Junta de Andalucía, 
Spain. We acknowledge the Brazilian Navy for field research support in Antarctica and at

Trindade Island, for collecting data of Southern Giant Petrels and Trindade Petrels respectively.

The project received funding from the National Institute of Science and Technology Antarctic

Environmental Research (INCT-APA) that receives scientific and financial support from the

National Council for Research and Development (CNPq process: $\mathrm{n}^{\circ}$ 574018/2008-5) and Carlos

Chagas Research Support Foundation of the State of Rio de Janeiro (FAPERJ $n^{\circ}$ E-

16/170.023/2008). The authors also acknowledge the support of the Brazilian Ministries of

Science, Technology and Innovation (MCTI), of Environment (MMA) and Inter-Ministry

Commission for Sea Resources (CIRM). We thank Maria Días from BirdLife International for

providing support with the seabird tracking database. We thank Ben Lascelles from BirdLife

International for providing the mIBA shapefiles. This study benefited from the strategic

program of MARE, financed by FCT (MARE - UID/MAR/04292/2013).

\section{References}

Acha, E.M., Mianzan, H.W., Guerrero, R. a, Favero, M. \& Bava, J. (2004). Marine fronts at the continental shelves of austral South America. J. Mar. Syst. 44, 83-105.

Anderson, O.R.J., Small, C.J., Croxall, J.P., Dunn, E.K., Sullivan, B.J., Yates, O. \& Black, A. (2011). Global seabird bycatch in longline fisheries. Endanger. Species Res.

Araújo, M.B. \& Guisan, A. (2006). Five (or so) challenges for species distribution modelling. J. Biogeogr. 33, 1677-1688.

Arcos, J.M., Bécares, J., Villero, D., Brotons, L., Rodríguez, B. \& Ruiz, A. (2012). Assessing the location and stability of foraging hotspots for pelagic seabirds: An approach to identify marine Important Bird Areas (IBAs) in Spain. Biol. Conserv. 156, 30-42.

Austin, M. (2007). Species distribution models and ecological theory: A critical assessment and some possible new approaches. Ecol. Modell. 200, 1-19.

Becker, B.H. \& Beissinger, S.R. (2006). Centennial Decline in the Trophic Level of an Endangered Seabird after Fisheries Decline. Conserv. Biol. 20, 470-479.

Birdlife International (2015) Marine IBA e-atlas: delivering site networks for seabird conservation. <https://maps.birdlife.org/marineIBAs/default.html >

Black, A. (2005). Light induced seabird mortality on vessels operating in the Southern Ocean: incidents and mitigation measures. Antarct. Sci. 17, 67-68.

Blumentrath, S. (2011). Site prioritisation models and their suitability for assessing and designing policy mixes for biodiversity conservation and ecosystem services provision: a comparison of software packages. POLICYMIX Policy Technical Brief 4, 1-10.

Bugoni, L., Mancini, P., Monteiro, D., Nascimento, L. \& Neves, T. (2008). Seabird bycatch in the Brazilian pelagic longline fishery and a review of capture rates in the southwestern Atlantic Ocean. Endanger. Species Res. 5, 137-147.

Burls, N.J. \& Reason, C.J.C. (2006). Sea surface temperature fronts in the midlatitude South Atlantic revealed by using microwave satellite data. J. Geophys. Res. 111, C08001.

Camphuysen, C.J. \& Heubeck, M. (2001). Marine oil pollution and beached bird surveys: the development of a sensitive monitoring instrument. Environ. Pollut. 112, 443-61.

Cao, L. \& Caldeira, K. (2008). Atmospheric CO 2 stabilization and ocean acidification. 
Catry, P., Dias, M.P., Phillips, R.A. \& Granadeiro, J.P. (2013). Carry-over effects from breeding modulate the annual cycle of a long-distance migrant: an experimental demonstration. Ecology 94, 1230-1235.

Charles, A. \& Wilson, L. (2009). Human dimensions of marine protected areas. ICES J. Mar. Sci. J. du Cons. 66, 6-15.

Codarin, A., Wysocki, L.E., Ladich, F. \& Picciulin, M. (2009). Effects of ambient and boat noise on hearing and communication in three fish species living in a marine protected area (Miramare, Italy). Mar. Pollut. Bull. 58, 1880-7.

Conroy, M.J., Runge, M.C., Nichols, J.D., Stodola, K.W. \& Cooper, R.J. (2011). Conservation in the face of climate change: The roles of alternative models, monitoring, and adaptation in confronting and reducing uncertainty. Biol. Conserv. 144, 1204-1213.

Croxall, J.P., Butchart, S.H.M., Lascelles, B., Stattersfield, A.J., Sullivan, B., Symes, A. \& Taylor, P. (2012). Seabird conservation status, threats and priority actions: a global assessment. Bird Conserv. Int. 22, 1-34.

Croxall, J.P., Silk, J.R.D., Phillips, R.A., Afanasyev, V. \& Briggs, D.R. (2005). Global Circumnavigations: Tracking Year-Round Ranges of Nonbreeding Albatrosses. Science. 307, 249-250.

Croxall, J.P. \& Wood, a. G. (2002). The importance of the Patagonian Shelf for top predator species breeding at South Georgia. Aquat. Conserv. Mar. Freshw. Ecosyst. 12, 101-118.

Cury, P.M., Boyd, I.L., Bonhommeau, S., Anker-nilssen, T., Crawford, R.J.M., Furness, R.W., Mills, J.A., Murphy, E.J., Österblom, H., Paleczny, M., Piatt, J.F. \& Roux, J. (2011). Global Seabird Response to Forage Fish Depletion - One Third for the Birds. Science. 334, $1703-1706$.

Dalton, T.M. (2004). An approach for integrating economic impact analysis into the evaluation of potential marine protected area sites. J. Environ. Manage. 70, 333-349.

Delavenne, J., Metcalfe, K., Smith, R.J., Vaz, S., Martin, C.S., Dupuis, L., Coppin, F. \& Carpentier, A. (2012). Systematic conservation planning in the eastern English Channel: comparing the Marxan and Zonation decision-support tools. ICES J. Mar. Sci. 69, 75-83.

Delord, K., Barbraud, C., Bost, C.-A., Deceuninck, B., Lefebvre, T., Lutz, R., Micol, T., Phillips, R. a., Trathan, P.N. \& Weimerskirch, H. (2014). Areas of importance for seabirds tracked from French southern territories, and recommendations for conservation. Mar. Policy 48, 1-13.

Dias, M.P., Granadeiro, J.P. \& Catry, P. (2013). Individual variability in the migratory path and stopovers of a long-distance pelagic migrant. Anim. Behav. 86, 359-364.

Dias, M.P., Granadeiro, J.P., Phillips, R. a, Alonso, H. \& Catry, P. (2011). Breaking the routine: individual Cory's shearwaters shift winter destinations between hemispheres and across ocean basins. Proc. Biol. Sci. 278, 1786-93.

Dunn, D.C., Ardron, J., Bax, N., Bernal, P., Cleary, J., Cresswell, I., Donnelly, B., Dunstan, P., Gjerde, K., Johnson, D., Kaschner, K., Lascelles, B., Rice, J., von Nordheim, H., Wood, L. \& Halpin, P.N. (2014). The Convention on Biological Diversity's Ecologically or Biologically Significant Areas: Origins, development, and current status. Mar. Policy 49, 137-145.

Edgar, G.J., Stuart-Smith, R.D., Willis, T.J., Kininmonth, S., Baker, S.C., Banks, S., Barrett, N.S., Becerro, M. a., Bernard, A.T.F., Berkhout, J., Buxton, C.D., Campbell, S.J., Cooper, A.T., Davey, M., Edgar, S.C., Försterra, G., Galván, D.E., Irigoyen, A.J., Kushner, D.J., Moura, R., Parnell, P.E., Shears, N.T., Soler, G., Strain, E.M. a. \& Thomson, R.J. (2014). Global conservation outcomes depend on marine protected areas with five key features. Nature 506, 216-220.

Edrén, S.M.C., Wisz, M.S., Teilmann, J., Dietz, R. \& Söderkvist, J. (2010). Modelling spatial patterns in harbour porpoise satellite telemetry data using maximum entropy. Ecography. 33, 698-708.

Glass, J. \& Ryan, P. (2013). Reduced seabird night strikes and mortality in the Tristan rock lobster fishery. African J. Mar. Sci. 35, 589-592.

González-Solís, J., Croxall, J.P. \& Afanasyev, V. (2008). Offshore spatial segregation in giant 
petrels Macronectes spp.: differences between species, sexes and seasons. Aquat. Conserv. Mar. Freshw. Ecosyst. 17, S22-S36.

González-Solís, J., Felicísimo, a, Fox, J., Afanasyev, V., Kolbeinsson, Y. \& Muñoz, J. (2009). Influence of sea surface winds on shearwater migration detours. Mar. Ecol. Prog. Ser. 391, 221-230.

Grecian, W.J., Witt, M.J., Attrill, M.J., Bearhop, S., Godley, B.J., Grémillet, D., Hamer, K.C. \& Votier, S.C. (2012). A novel projection technique to identify important at-sea areas for seabird conservation: An example using Northern gannets breeding in the North East Atlantic. Biol. Conserv. 156, 43-52.

Gregg, W.W., Casey, N.W. \& McClain, C.R. (2005). Recent trends in global ocean chlorophyll. Geophys. Res. Lett. 32, 1-5.

Grémillet, D. \& Boulinier, T. (2009). Spatial ecology and conservation of seabirds facing global climate change: a review. Mar. Ecol. Prog. Ser. 391, 121-137.

Grémillet, D., Lewis, S., Drapeau, L., van Der Lingen, C.D., Huggett, J. a., Coetzee, J.C., Verheye, H.M., Daunt, F., Wanless, S. \& Ryan, P.G. (2008). Spatial match-mismatch in the Benguela upwelling zone: should we expect chlorophyll and sea-surface temperature to predict marine predator distributions? J. Appl. Ecol. 45, 610-621.

Grémillet, D., Wilson, R.P., Wanless, S. \& Chater, T. (2000). Black-browed albatrosses, international fisheries and the Patagonian Shelf. Mar. Ecol. Prog. Ser. 195, 269-280.

Hale, R., Calosi, P., McNeill, L., Mieszkowska, N. \& Widdicombe, S. (2011). Predicted levels of future ocean acidification and temperature rise could alter community structure and biodiversity in marine benthic communities. Oikos 120, 661-674.

Halpern, B.S., Frazier, M., Potapenko, J., Casey, K.S., Koenig, K., Longo, C., Lowndes, J.S., Rockwood, R.C., Selig, E.R., Selkoe, K.A. \& Walbridge, S. (2015). Spatial and temporal changes in cumulative human impacts on the world's ocean. Nat. Commun. 6, 7615.

Halpern, B.S., Walbridge, S., Selkoe, K. a, Kappel, C. V, Micheli, F., D’Agrosa, C., Bruno, J.F., Casey, K.S., Ebert, C., Fox, H.E., Fujita, R., Heinemann, D., Lenihan, H.S., Madin, E.M.P., Perry, M.T., Selig, E.R., Spalding, M., Steneck, R. \& Watson, R. (2008). A global map of human impact on marine ecosystems. Science. 319, 948-52.

Harvey, B.P., Gwynn-Jones, D. \& Moore, P.J. (2013). Meta-analysis reveals complex marine biological responses to the interactive effects of ocean acidification and warming. Ecol. Evol. 3, 1016-30.

Hatch, L., Clark, C., Merrick, R., Van Parijs, S., Ponirakis, D., Schwehr, K., Thompson, M. \& Wiley, D. (2008). Characterizing the relative contributions of large vessels to total ocean noise fields: A case study using the Gerry E. studds stellwagen bank national marine sanctuary. Environ. Manage. 42, 735-752.

Hooker, S.K. \& Gerber, L.R. (2004). Marine Reserves as a Tool for Ecosystem-Based Management: The Potential Importance of Megafauna. Bioscience 54, 27-39.

Horta e Costa, B., Batista, M.I., Gonçalves, L., Erzini, K., Caselle, J.E., Cabral, H.N. \& Gonçalves, E.J. (2013a). Fishers' Behaviour in Response to the Implementation of a Marine Protected Area. PLoS One 8, e65057.

Horta e Costa, B., Gonçalves, L. \& Gonçalves, E.J. (2013b). Vessels' site fidelity and spatiotemporal distribution of artisanal fisheries before the implementation of a temperate multiple-use marine protected area. Fish. Res. 148, 27-37.

Hyrenbach, K.D., Forney, K.A. \& Dayton, P.K. (2000). Marine protected areas and ocean basin management. Aquat. Conserv. Mar. Freshw. Ecosyst. 10, 437-458.

Irwin, A.J. \& Oliver, M.J. (2009). Are ocean deserts getting larger? Geophys. Res. Lett. 36, 1-5. Jameson, S.C., Tupper, M.H. \& Ridley, J.M. (2002). The three screen doors: can marine "protected" areas be effective? Mar. Pollut. Bull. 44, 1177-83.

Jiménez, S., Abreu, M., Pons, M., Ortiz, M. \& Domingo, A. (2010). Assessing the impact of the pelagic longline fishery on albatrosses and petrels in the southwest Atlantic. Aquat. Living Resour. 23, 49-64.

Jiménez, S., Domingo, A., Brazeiro, A., Defeo, O. \& Phillips, R.A. (2015). Marine debris ingestion by albatrosses in the southwest Atlantic Ocean. Mar. Pollut. Bull. 96, 149-154.

Kachelriess, D., Wegmann, M., Gollock, M. \& Pettorelli, N. (2014). The application of remote 
sensing for marine protected area management. Ecol. Indic. 36, 169-177.

Kark, S., Brokovich, E., Mazor, T. \& Levin, N. (2015). Emerging conservation challenges and prospects in an era of offshore hydrocarbon exploration and exploitation. Conserv. Biol. 29, 1573-1585.

Karpouzi, V.S., Watson, R. \& Pauly, D. (2007). Modelling and mapping resource overlap between seabirds and fisheries on a global scale: A preliminary assessment. Mar. Ecol. Prog. Ser. 343, 87-99.

Kelleher, G. (1999). Guidelines for marine protected areas. Best Pract. Prot. Area Guidel. Ser. Wales, UK: World Commission on Protected Areas of IUCN - The World Conservation Union.

Kitchingman, A., Lai, S., Morato, T. \& Pauly, D. (2008). How many seamounts are there and where are they located? In Seamounts: Ecology, Fisheries \& Conservation: 26-40.

Krüger, L., Paiva, V.H., Petry, M. V. \& Ramos, J.A. (2016a). Strange lights in the night: using abnormal peaks of light in geolocator data to infer interaction of seabirds with nocturnal fishing vessels. Polar Biol. 10.1007/s00300-016-1933-y.

Krüger, L., Paiva, V.H., Colabuono, F.I., Petry, M. V., Montone, R.C. \& Ramos, J.A. (2016b). Year-round spatial movements and trophic ecology of Trindade Petrels (Pterodroma arminjoniana ). J. F. Ornithol. 10.1111/jofo.12175Krüger, L. \& Petry, M.V. (2011). On the Relation of Antarctic and Subantarctic Seabirds With Abiotic Variables off South and Southeast Brazil. Oecologia Aust. 15, 51-58.

Lascelles, B.G., Langham, G.M., Ronconi, R. a. \& Reid, J.B. (2012). From hotspots to site protection: Identifying Marine Protected Areas for seabirds around the globe. Biol. Conserv. 156, 5-14.

Lascelles, B.G., Taylor, P.R., Miller, M.G.R., Dias, M.P., Oppel, S., Torres, L., Hedd, A., Le Corre, M., Phillips, R.A., Shaffer, S.A., Weimerskirch, H. \& Small, C. (2016). Applying global criteria to tracking data to define important areas for marine conservation. Divers. Distrib. 10.1111/ddi.12411.

Leathwick, J., Moilanen, A., Francis, M., Elith, J., Taylor, P., Julian, K., Hastie, T. \& Duffy, C. (2008). Novel methods for the design and evaluation of marine protected areas in offshore waters. Conserv. Lett. 1, 91-102.

Lebreton, L.C.-M., Greer, S.D. \& Borrero, J.C. (2012). Numerical modelling of floating debris in the world's oceans. Mar. Pollut. Bull. 64, 653-61.

Lewison, R.L., Crowder, L.B., Wallace, B.P., Moore, J.E., Cox, T., Zydelis, R., McDonald, S., DiMatteo, A., Dunn, D.C., Kot, C.Y., Bjorkland, R., Kelez, S., Soykan, C., Stewart, K.R., Sims, M., Boustany, A., Read, A.J., Halpin, P., Nichols, W.J. \& Safina, C. (2014). Global patterns of marine mammal, seabird, and sea turtle bycatch reveal taxa-specific and cumulative megafauna hotspots. Proc. Natl. Acad. Sci. U. S. A. 111, 5271-6.

Li, Y., Fratantoni, P.S., Chen, C., Hare, J.A., Sun, Y., Beardsley, R.C. \& Ji, R. (2015). Spatiotemporal patterns of stratification on the Northwest Atlantic shelf. Prog. Oceanogr. 134, 123-137.

Mackley, E.K., Phillips, R. a., Silk, J.R.D., Wakefield, E.D., Afanasyev, V. \& Furness, R.W. (2010). At-sea activity patterns of breeding and nonbreeding white-chinned petrels Procellaria aequinoctialis from South Georgia. Mar. Biol. 158, 429-438.

Mann, K.H. \& Lazier, J.R.N. (2006). Dynamics of Marine Ecosystems: biological-physical interactions in the oceans. Dartmouth: Blackwell.

Marine Conservation Institute (2015) MPAtlas. < http://www.mpatlas.org/>

Mazor, T., Giakoumi, S., Kark, S. \& Possingham, H.P. (2014). Large-scale conservation planning in a multinational marine environment: Cost matters. Ecol. Appl. 24, 1115-1130.

Merow, C., Smith, M.J. \& Silander, J.A. (2013). A practical guide to MaxEnt for modeling species' distributions: What it does, and why inputs and settings matter. Ecography. 36, $1058-1069$.

Michael, P.E., Jahncke, J. \& Hyrenbach, K.D. (2014). Relative influence of static and dynamic features on black-footed albatross (Phoebastria nigripes) habitat use in central California Sanctuaries. Fish. Oceanogr. 23, 18-31.

Miloslavich, P., Klein, E., Díaz, J.M., Hernández, C.E., Bigatti, G., Campos, L., Artigas, F., 
Castillo, J., Penchaszadeh, P.E., Neill, P.E., Carranza, A., Retana, M. V., Díaz de Astarloa, J.M., Lewis, M., Yorio, P., Piriz, M.L., Rodríguez, D., Yoneshigue-Valentin, Y., Gamboa, L. \& Martín, A. (2011). Marine Biodiversity in the Atlantic and Pacific Coasts of South America: Knowledge and Gaps. PLoS One 6, e14631.

Missagia, R. V., Ramos, J.A., Louzao, M., Delord, K., Weimerskirch, H. \& Paiva, V.H. (2015). Year-round distribution suggests spatial segregation of Cory's shearwaters, based on individual experience. Mar. Biol. 162, 2279-2289.

Moilanen, A., Franco, A.M. a, Early, R.I., Fox, R., Wintle, B. \& Thomas, C.D. (2005). Prioritizing multiple-use landscapes for conservation: methods for large multi-species planning problems. Proc. R. Soc. Biol. Sci. 272, 1885-1891.

Moilanen, A. \& Wintle, B.A. (2006). Uncertainty analysis favours selection of spatially aggregated reserve networks. Biol. Conserv. 129, 427-434.

Moilanen, A. \& Wintle, B.A. (2007). The boundary-quality penalty: A quantitative method for approximating species responses to fragmentation in reserve selection. Conserv. Biol. 21, 355-364.

Montevecchi, W. a., Hedd, a., McFarlane Tranquilla, L., Fifield, D. a., Burke, C.M., Regular, P.M., Davoren, G.K., Garthe, S., Robertson, G.J. \& Phillips, R. a. (2012). Tracking seabirds to identify ecologically important and high risk marine areas in the western North Atlantic. Biol. Conserv. 156, 62-71.

Mora, C. \& Sale, P.F. (2011). Ongoing global biodiversity loss and the need to move beyond protected areas: A review of the technical and practical shortcomings of protected areas on land and sea. Mar. Ecol. Prog. Ser. 434, 251-266.

Moreno, R., Jover, L., Diez, C., Sardà, F. \& Sanpera, C. (2013). Ten years after the prestige oil spill: seabird trophic ecology as indicator of long-term effects on the coastal marine ecosystem. PLoS One 8, e77360.

Morton, A.B. \& Symonds, H.K. (2002). Displacement of Orcinus orca (L.) by high amplitude sound in British Columbia, Canada. ICES J. Mar. Sci. 59, 71-80.

Navarro, J., Cardador, L., Brown, R. \& Phillips, R. a. (2015). Spatial distribution and ecological niches of non-breeding planktivorous petrels. Sci. Rep. 5, 12164.

Nicholls, D.G., Robertson, C.J.R., Prince, P.A., Murray, M.D., Walker, K.J. \& Elliott, G.P. (2002). Foraging niches of three Diomedea albatrosses. Mar. Ecol. Prog. Ser. 231, 269277.

Nielsen, A. \& Sibert, J.R. (2007). State-space model for light-based tracking of marine animals. Can. J. Fish. Aquat. Sci. 64, 1055-1068.

Oksanen, J., Blanchet, F.G., Kindt, R., Legendre, P., Minchin, P.R., O’Hara, R.B., Simpson, G.L., Solymos, P., Stevens, M.H.H. \& Wagner, H. (2013). Community ecology package. $<$ http://cran.r-project.org, http://vegan>

Oppel, S., Meirinho, A., Ramírez, I., Gardner, B., O’Connell, A.F., Miller, P.I. \& Louzao, M. (2012). Comparison of five modelling techniques to predict the spatial distribution and abundance of seabirds. Biol. Conserv. 156, 94-104.

Péron, C., Authier, M., Barbraud, C., Delord, K., Besson, D. \& Weimerskirch, H. (2010). Interdecadal changes in at-sea distribution and abundance of subantarctic seabirds along a latitudinal gradient in the Southern Indian Ocean. Glob. Chang. Biol. 16, 1895-1909.

Petry, M. V \& Fonseca, V.S.S. (2002). Effects of Human Activities in the Marine Environment on Seabirds Along the Coast of Rio Grande Do Sul , Brazil. Ornitol. Neotrop. 13, 137142 .

Phillips, R., Silk, J., Croxall, J., Afanasyev, V. \& Briggs, D. (2004). Accuracy of geolocation estimates for flying seabirds. Mar. Ecol. Prog. Ser. 266, 265-272.

Phillips, R.A., Silk, J.R.D., Croxall, J.P. \& Afanasyev, V. (2006a). Year-round distribution of white-chinned petrels from South Georgia: Relationships with oceanography and fisheries. Biol. Conserv. 129, 336-347.

Phillips, S.J., Anderson, R.P. \& Schapire, R.E. (2006b). Maximum entropy modeling of species geographic distributions. Ecol. Modell. 190, 231-259.

Pinet, P., Jaquemet, S., Pinaud, D., Weimerskirch, H., Phillips, R. \& Le Corre, M. (2011). Migration, wintering distribution and habitat use of an endangered tropical seabird, 
Barau's petrel Pterodroma baraui. Mar. Ecol. Prog. Ser. 423, 291-302.

Pitchford, J.W., Codling, E. a. \& Psarra, D. (2007). Uncertainty and sustainability in fisheries and the benefit of marine protected areas. Ecol. Modell. 207, 286-292.

Polidoro, B.A., Carpenter, K.E., Collins, L., Duke, N.C., Ellison, A.M., Ellison, J.C., Farnsworth, E.J., Fernando, E.S., Kathiresan, K., Koedam, N.E., Livingstone, S.R., Miyagi, T., Moore, G.E., Nam, V.N., Ong, J.E., Primavera, J.H., Salmo, S.G., Sanciangco, J.C., Sukardjo, S., Wang, Y. \& Yong, J.W.H. (2010). The loss of species: Mangrove extinction risk and geographic areas of global concern. PLoS One 5.

Polovina, J.J., Howell, E.A. \& Abecassis, M. (2008). Ocean's least productive waters are expanding. Geophys. Res. Lett. 35, 2-6.

Pomeroy, R.S., Watson, L.M., Parks, J.E. \& Cid, G. a. (2005). How is your MPA doing? A methodology for evaluating the management effectiveness of marine protected areas. Ocean Coast. Manag. 48, 485-502.

Pörtner, H.O. \& Peck, M.A. (2010). Climate change effects on fishes and fisheries: Towards a cause-and-effect understanding. J. Fish Biol. 77, 1745-1779.

Quillfeldt, P., Cherel, Y., Delord, K. \& Weimerkirch, H. (2015). Cool, cold or colder? Spatial segregation of prions and blue petrels is explained by differences in preferred sea surface temperatures. Biol. Lett. 11, 2014090.

Quillfeldt, P., Masello, J.F., Navarro, J. \& Phillips, R.A. (2013). Year-round distribution suggests spatial segregation of two small petrel species in the South Atlantic. J. Biogeogr. 40, 430-441.

Ramírez, I., Paiva, V., Menezes, D., Silva, I., Phillips, R., Ramos, J. \& Garthe, S. (2013). Yearround distribution and habitat preferences of the Bugio petrel. Mar. Ecol. Prog. Ser. 476, 269-284.

Reid, T., Wanless, R., Hilton, G., Phillips, R. \& Ryan, P. (2013). Foraging range and habitat associations of nonbreeding Tristan albatrosses: overlap with fisheries and implications for conservation. Endanger. Species Res. 22, 39-49.

Rife, A.N., Aburto-Oropeza, O., Hastings, P. a, Erisman, B., Ballantyne, F., Wielgus, J., Sala, E. \& Gerber, L. (2013). Long-term effectiveness of a multi-use marine protected area on reef fish assemblages and fisheries landings. J. Environ. Manage. 117, 276-83.

Roberts, C.M., McClean, C.J., Veron, J.E.N., Hawkins, J.P., Allen, G.R., McAllister, D.E., Mittermeier, C.G., Schueler, F.W., Spalding, M., Wells, F., Vynne, C. \& Werner, T.B. (2002). Marine biodiversity hotspots and conservation priorities for tropical reefs. Science. 295, 1280-1284.

Rockström, J., Steffen, W., Noone, K., Persson, Å., Chapin, F.S., Lambin, E.F., Lenton, T.M., Scheffer, M., Folke, C., Schellnhuber, H.J., Nykvist, B., de Wit, C.A., Hughes, T., van der Leeuw, S., Rodhe, H., Sörlin, S., Snyder, P.K., Costanza, R., Svedin, U., Falkenmark, M., Karlberg, L., Corell, R.W., Fabry, V.J., Hansen, J., Walker, B., Liverman, D., Richardson, K., Crutzen, P. \& Foley, J.A. (2009). A safe operating space for humanity. Nature 461, $472-475$.

Ronconi, R.A., Lascelles, B.G., Langham, G.M., Reid, J.B. \& Oro, D. (2012). The role of seabirds in Marine Protected Area identification, delineation, and monitoring: Introduction and synthesis. Biol. Conserv. 156, 1-4.

Ronconi, R.A., Ryan, P.G. \& Ropert-Coudert, Y. (2010). Diving of great shearwaters (Puffinus gravis) in cold and warm water regions of the South Atlantic Ocean. PLoS One 5, 1-7.

Van Sebille, E. (2015). The oceans' accumulating plastic garbage. Phys. Today 68, 60-61.

Van Sebille, E., England, M.H. \& Froyland, G. (2012). Origin, dynamics and evolution of ocean garbage patches from observed surface drifters. Environ. Res. Lett. 7, 044040.

Secretariat of the Convention on Biological Diversity. (2006). Convention on Biological Diversity: Year in Review 2006.

Selig, E.R., Turner, W.R., Troëng, S., Wallace, B.P., Halpern, B.S., Kaschner, K., Lascelles, B.G., Carpenter, K.E. \& Mittermeier, R.A. (2014). Global priorities for marine biodiversity conservation. PLoS One $\mathbf{9}, 1-11$.

Sergio, F., Caro, T., Brown, D., Clucas, B., Hunter, J., Ketchum, J., McHugh, K. \& Hiraldo, F. (2008). Top Predators as Conservation Tools: Ecological Rationale, Assumptions, and 
Efficacy. Annu. Rev. Ecol. Evol. Syst. 39, 1-19.

Sidhu, L., Dann, P., Chambers, L. \& Catchpole, E. (2012). Seasonal ocean temperature and the survival of first-year little penguins Eudyptula minor in south-eastern Australia. Mar. Ecol. Prog. Ser. 454, 263-272.

Stevenson, T.C., Tissot, B.N. \& Walsh, W.J. (2013). Socioeconomic consequences of fishing displacement from marine protected areas in Hawaii. Biol. Conserv. 160, 50-58.

Sundblad, G., Bergström, U. \& Sandström, A. (2011). Ecological coherence of marine protected area networks: A spatial assessment using species distribution models. J. Appl. Ecol. 48, $112-120$.

Tancell, C., Phillips, R. a., Xavier, J.C., Tarling, G. a. \& Sutherland, W.J. (2012). Comparison of methods for determining key marine areas from tracking data. Mar. Biol. 160, 15-26.

Thaxter, C.B., Lascelles, B., Sugar, K., Cook, A.S.C.P., Roos, S., Bolton, M., Langston, R.H.W. \& Burton, N.H.K. (2012). Seabird foraging ranges as a preliminary tool for identifying candidate Marine Protected Areas. Biol. Conserv. 156, 53-61.

Thiebot, J., Delord, K., Marteau, C. \& Weimerskirch, H. (2014). Stage-dependent distribution of the Critically Endangered Amsterdam albatross in relation to Economic Exclusive Zones. Endanger. Species Res. 23, 263-276.

Titmus, A.J. \& Hyrenbach, K.D. (2011). Habitat associations of floating debris and marine birds in the North East Pacific Ocean at coarse and meso spatial scales. Mar. Pollut. Bull. 62, 2496-2506.

Tittensor, D.P., Mora, C., Jetz, W., Lotze, H.K., Ricard, D., Berghe, E. Vanden \& Worm, B. (2010). Global patterns and predictors of marine biodiversity across taxa. Nature 466, 1098-101.

Valdés, L., Peterson, W., Church, J., Brander, K. \& Marcos, M. (2009). Our changing oceans: conclusions of the first International Symposium on the Effects of climate change on the world' s oceans. ICES J. Mar. Sci. 66, 1435-1438.

Vasconcellos, M. \& Csirke, J. (2011). Southwest Atlantic: FAO Statistical Area 41. In Review of the state of world marine fishery resources: 93-105. Food and Agriculture Organization (FAO) (Ed). Rome: FAO.

Wakefield, E.D., Phillips, R. a. \& Belchier, M. (2012). Foraging black-browed albatrosses target waters overlaying moraine banks - a consequence of upward benthic-pelagic coupling? Antarct. Sci. 24, 269-280.

Weilgart, L.S. (2007). The impacts of anthropogenic ocean noise on cetaceans and implications for management. Can. J. Zool. 85, 1091-1116.

White, R.W., Gillon, K.W., Black, A.D. \& Reid, J.B. (2002). The Distribution of Seabirds and Marine Mammals in Falkland Islands waters. Peterborough: Joint Nature Conservation Committee.

Wiese, F.K. \& Robertson, G.J. (2004). Assessing seabird mortality from chronic oil discharges at sea. J. Wildl. Manage. 68, 627-638.

Wilcox, C., Van Sebille, E. \& Hardesty, B.D. (2015). Threat of plastic pollution to seabirds is global, pervasive, and increasing. Proc. Natl. Acad. Sci. U. S. A. 112, 11899-11904.

Wilson, R.P., Ducamp, J.J., Rees, W.G., Culik, B.M. \& Niekamp, K. (1992). Estimation of location: global coverage using light intensity. In Wildlife telemetry: remote monitoring and tracking of animals: 131-134.

Xavier, J.C., Trathan, P.N., Croxall, J.P., Wood, A.G., Podestá, G. \& Rodhouse, P.G. (2004). Foraging ecology and interactions with fisheries of wandering albatrosses (Diomedea exulans) breeding at South Georgia. Fish. Oceanogr. 13, 324-344.

Yorio, P. (2009). Marine protected areas, spatial scales, and governance: implications for the conservation of breeding seabirds. Conserv. Lett. 2, 171-178.

Yorio, P., Frere, E., Gandini, P. \& Conway, W. (1999). Status and conservation of seabirds breeding in Argentina. Bird Conserv. Int. 9, 299-314.

Zuur, A.F., Ieno, E.N. \& Smith, G.M. (2007). Analysing Ecological Data. Profiles Drug Subst. Excip. Relat. Methodol. New York, NY: Springer. 
Table 1 Seabird species included in the study. Smoothing cell size corresponds to the number of grid cells used for distribution smoothing in Zonation software for the analysis of habitat connectivity, and reflects the minimum area of habitat required for a species to occur. Cell sizes differ according to body size, following the approach of Leathwick et al (2008). Each species was assigned to one of two assemblages based on its core distribution relative to the mean position of the northern boundary of the Subtropical Front (Burls and Reason 2006): Temperate (TE) and tropical (TR) species. IUCN Status: LC=Least Concern, NT=Near Threatened, VU=Vulnerable, EN=Endangered, $\mathrm{CR}=$ Critically Endangered. Colony of the tracked animals is presented. Number of tracked individuals $(\mathrm{N})$, tracked years and source of the tracking data.

\begin{tabular}{|c|c|c|c|c|c|c|c|c|c|}
\hline CommonName & Species & $\begin{array}{c}\text { Abbreviatio } \\
n\end{array}$ & $\begin{array}{c}\text { Size Range } \\
(\mathrm{cm})\end{array}$ & $\begin{array}{c}\text { Assemblag } \\
\mathrm{e}\end{array}$ & $\begin{array}{l}\text { IUCN } \\
\text { Status } \\
\end{array}$ & Colony & $\mathrm{N}$ & Years & Source \\
\hline Tristan Albatross & $\begin{array}{l}\text { Diomedea } \\
\text { dabbenena }\end{array}$ & TA & 110 & Northern & $\mathrm{CR}$ & Gough Island & 34 & $\begin{array}{l}2004, \\
2005, \\
2006\end{array}$ & $\begin{array}{l}\text { Reid et al } \\
\text { (2013) }\end{array}$ \\
\hline Wandering Albatross & Diomedea exulans & WA & $120-135$ & Southern & VU & Bird Island (South Georgia) & 18 & 2003 & $\begin{array}{l}\text { Mackley et } \\
\text { al (2010) }\end{array}$ \\
\hline $\begin{array}{l}\text { Black-browed } \\
\text { Albatross }\end{array}$ & $\begin{array}{l}\text { Thalassarche } \\
\text { melanophris }\end{array}$ & BBA & $80-96$ & Southern & NT & $\begin{array}{l}\text { Bird Island (South Georgia), New Island } \\
\text { (Falklands) }\end{array}$ & 57 & $\begin{array}{l}1996, \\
1997, \\
2002, \\
2003\end{array}$ & $\begin{array}{l}\text { Grémillet et } \\
\text { al (2000), } \\
\text { Mackley et } \\
\text { al (2010) }\end{array}$ \\
\hline $\begin{array}{l}\text { Grey-headed } \\
\text { Albatross }\end{array}$ & $\begin{array}{l}\text { Thalassarche } \\
\text { chrysostoma }\end{array}$ & GHA & $70-85$ & Southern & EN & Bird Island (South Georgia) & 35 & $\begin{array}{l}2003, \\
2006\end{array}$ & $\begin{array}{l}\text { Croxallet al } \\
\quad(2005)\end{array}$ \\
\hline Northern Giant Petrel & Macronectes halli & NGP & $80-95$ & Southern & $\mathrm{LC}$ & Bird Island (South Georgia) & 25 & $\begin{array}{l}1999, \\
2001\end{array}$ & $\begin{array}{l}\text { González- } \\
\text { Solís et al } \\
\text { (2008) }\end{array}$ \\
\hline Southern Giant Petrel & $\begin{array}{l}\text { Macronectes } \\
\text { giganteus }\end{array}$ & SGP & $85-100$ & Southern & $\mathrm{LC}$ & $\begin{array}{l}\text { Bird Island (South Georgia), Elephant Island } \\
\text { (South Shetlands) }\end{array}$ & 40 & $\begin{array}{l}1999, \\
2001, \\
2011\end{array}$ & $\begin{array}{l}\text { González- } \\
\text { Solís et al } \\
(2008), \\
\text { Krüger et al } \\
\quad(2016)\end{array}$ \\
\hline White-chinned Petrel & $\begin{array}{l}\text { Procellaria } \\
\text { aequinoctialis }\end{array}$ & WCP & $51-58$ & Southern & VU & South Georgia & 11 & $\begin{array}{l}2003, \\
2004\end{array}$ & $\begin{array}{l}\text { Phillips et } \\
\text { al (2006) }\end{array}$ \\
\hline Antarctic Prion & Pachyptila desolata & $\mathrm{AP}$ & $25-27$ & Southern & $\mathrm{LC}$ & South Georgia & 10 & $\begin{array}{l}2009 \\
2010\end{array}$ & $\begin{array}{l}\text { Quillfeldt et } \\
\text { al (2013) }\end{array}$ \\
\hline Deserta's Petrel & Pterodroma deserta & DP & 35 & Northern & VU & Bugio Island & 24 & $\begin{array}{l}2007, \\
2008, \\
2009,\end{array}$ & $\begin{array}{l}\text { Ramírez et } \\
\text { al (2013) }\end{array}$ \\
\hline
\end{tabular}




\begin{tabular}{|c|c|c|c|c|c|c|c|c|c|}
\hline Trindade & $\begin{array}{l}\text { Pterodroma } \\
\text { arminjoniana }\end{array}$ & $\mathrm{TP}$ & $37-40$ & Northern & $\mathrm{VU}$ & Trindade Island & 4 & $\begin{array}{c}2013,201 \\
4\end{array}$ & $\begin{array}{l}\text { Krüger et al } \\
\text { (2016.) }\end{array}$ \\
\hline Cory's Shearwater & Calonectris borealis & CS & 46 & Northern & LC & Berlenga, Azores and Canary Islands & 41 & $\begin{array}{l}2002, \\
2003, \\
2004, \\
2011, \\
2012\end{array}$ & $\begin{array}{l}\text { González- } \\
\text { Solís et al } \\
\text { (2009), } \\
\text { Missagia et } \\
\text { al (2016) }\end{array}$ \\
\hline Great Shearwater & Ardenna gravis & GS & $46-51$ & Southern & LC & Gough Island & 37 & $\begin{array}{l}2008- \\
2012\end{array}$ & $\begin{array}{l}\text { González- } \\
\text { Solís }\end{array}$ \\
\hline Manx Shearwater & Puffinus puffinus & MS & $30-35$ & Southern & LC & Heimeaey, Iceland & 10 & $\begin{array}{c}2006,200 \\
7\end{array}$ & $\begin{array}{l}\text { González- } \\
\text { Solíset al } \\
\text { (2009) }\end{array}$ \\
\hline $\begin{array}{l}\text { Cape Verde } \\
\text { Shearwater }\end{array}$ & $\begin{array}{l}\text { Calonectris } \\
\text { edwardsii }\end{array}$ & CVS & 34 & Northern & NT & Cape Verde Isalnds & 26 & $\begin{array}{c}2006,200 \\
7\end{array}$ & $\begin{array}{c}\text { González- } \\
\text { Solíset al } \\
\text { (2009) }\end{array}$ \\
\hline
\end{tabular}


Table 2 Percentage of proposed key areas overlapping and overlapped by the IBAs, EBSAs and current MPAs.

\begin{tabular}{lccccc}
\hline Assemblage & & $\begin{array}{c}\text { IBA } \\
\text { confirmed }\end{array}$ & $\begin{array}{c}\text { IBA } \\
\text { proposed }\end{array}$ & EBSA & MPAs \\
\hline South & Overlap with & 0.058 & 1.195 & 0.000 & 0.000 \\
North & & 0.000 & 0.382 & 3.559 & 0.002 \\
South & Overlapped by & 0.053 & 8.397 & 0.000 & 0.026 \\
North & & 0.000 & 1.139 & 15.345 & 0.037 \\
\hline
\end{tabular}




\section{List of Figures}

Figure 1 Canonical Correspondence Analysis bi-plots presenting the position of Northern species (red labels), Southern species (blue labels) and environmental - threats and coordinates - (black labels) for Summer (a), Winter (b) and all Year (c). Boxplots presenting the distribution frequency of the bi-dimensional distance of species from threats for Northern species during Summer (d), Winter (e) and all Year (f), and Southern species during Summer (g), Winter (h) and all Year (i). Top outliers in ' $h$ ' and 'i' are White-chinned Petrel values.

Figure 2 Zonation outputs in proportion to value based on the probability of occurrence of species given their weight and response to fragmentation for Summer (a), Winter (b) and yearround (c). Also shown the Official Marine Protected Areas (MPAs, red lines), Ecologically or Biologically Significant Areas (EBSAs; green lines; https://www.cbd.int/ebsa/) and confirmed (light blue lines) or proposed (dark blue lines) BirdLife marine IBAs (http://maps.birdlife.org/marineIBAs/default.html).

Figure 3 The zonation calculated area value in relation to the Species Occurrence Probability $(a, c, e)$ and number of species occurrence $(b, d, f)$. Linear trend for Southern (solid line) and Northern (dashed line) seabird assemblages.

Figure 4 Key marine areas for 99\% value threshold overlapped with Confirmed (light grey) or Proposed (dark grey) IBAs (http://maps.birdlife.org), Ecologically or Biologically Significant Marine Areas (EBSAs; dashed line; https://www.cbd.int/ebsa/) and designated MPAs (black line; http://www.mpatlas.org). Southern (1), Northern (2 and 3) seabirds during summer (red line), winter (blue line) and all year (green line).

Figure 5 Change in values (proportion of reduction) within the proposed marine areas (thresholds 90\%, 95\% and 99\%) when using Fishing and Ship Densities as cost layers to calculate importance values in Zonation. Southern (a) and Northern (b) seabirds. 

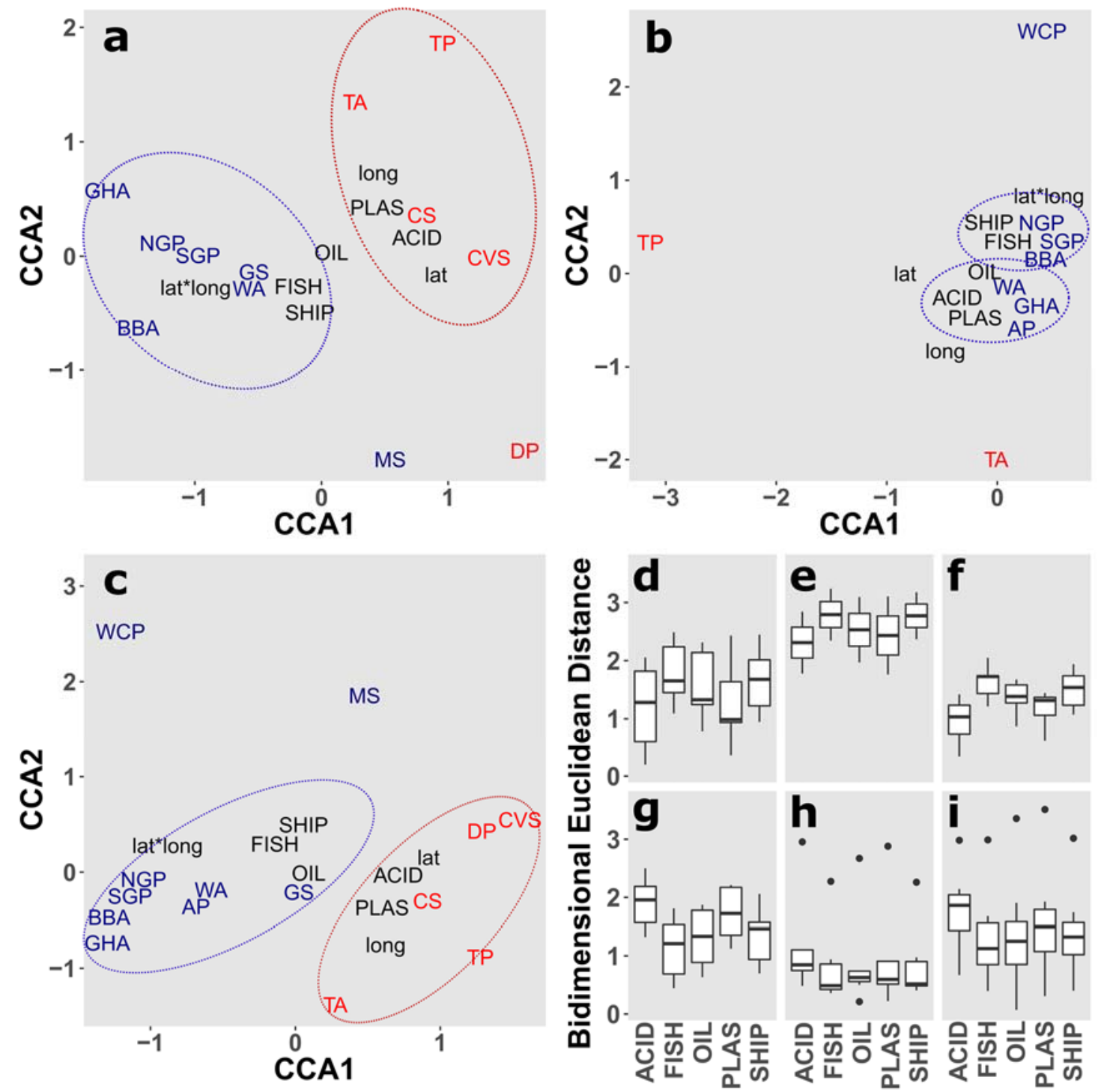

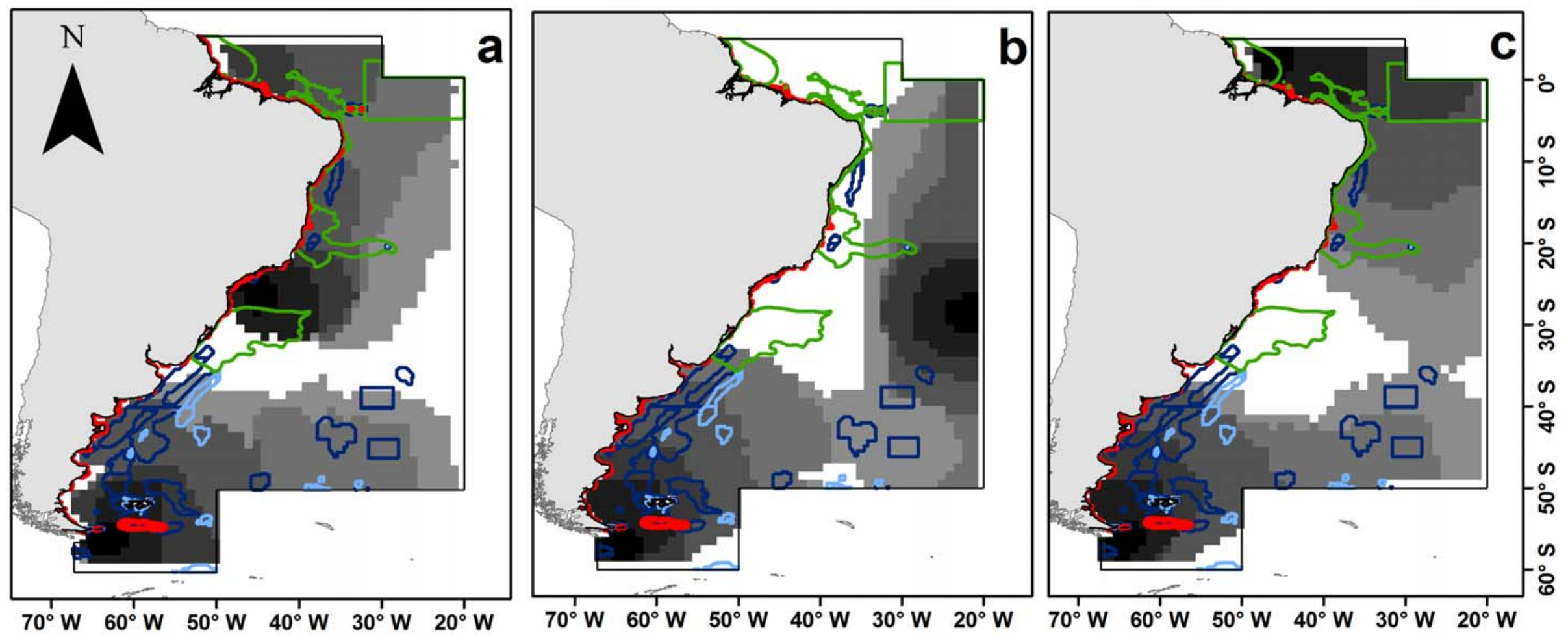

\section{Area Values}
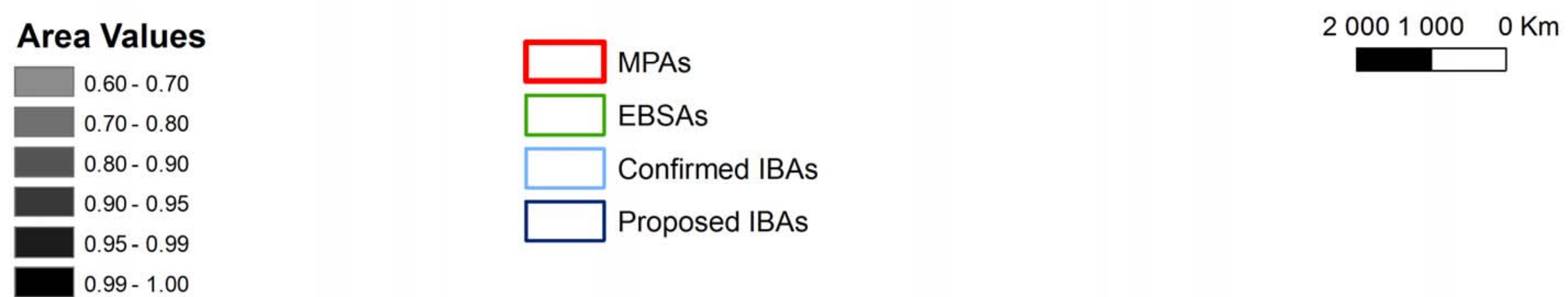

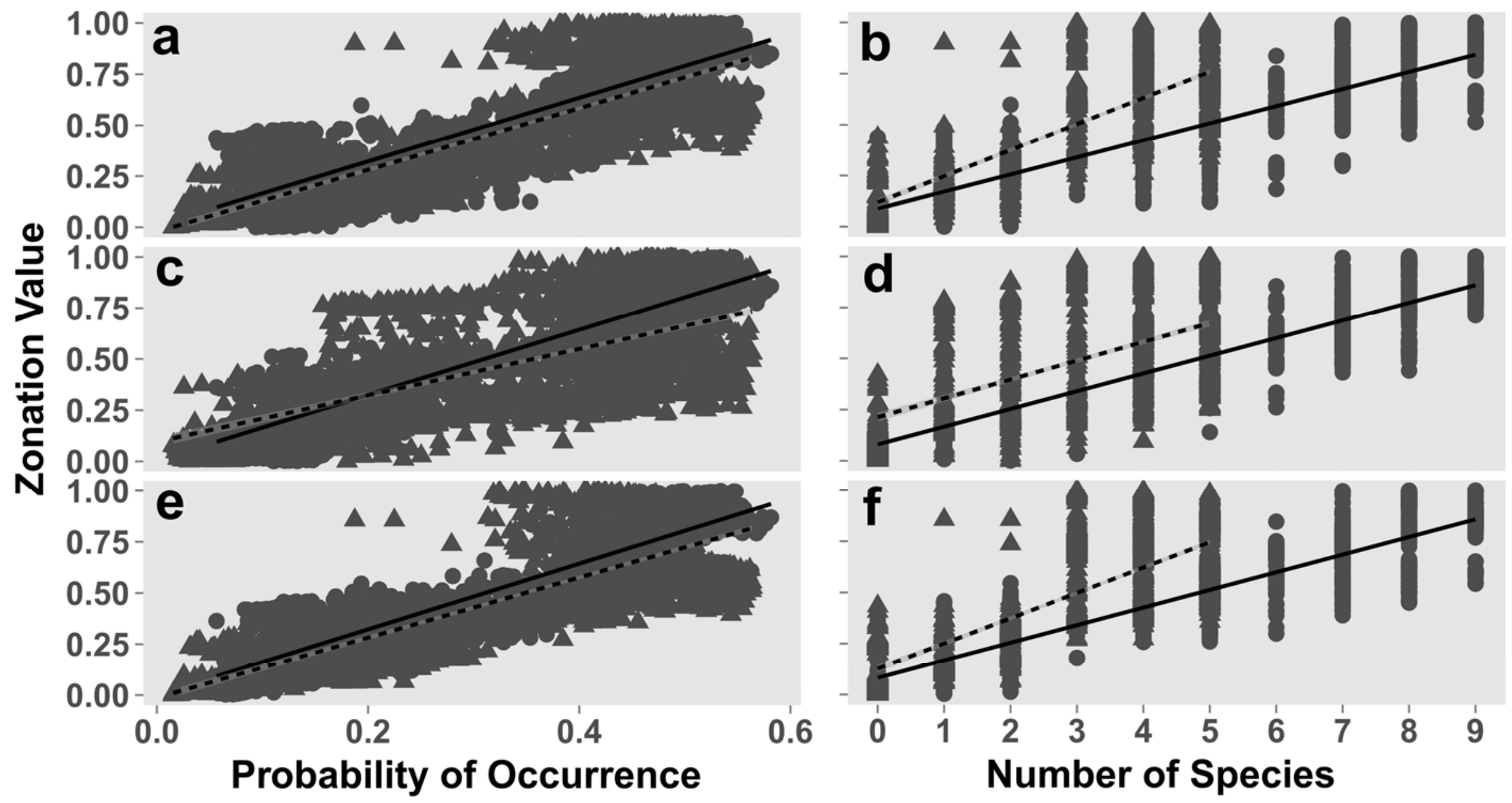

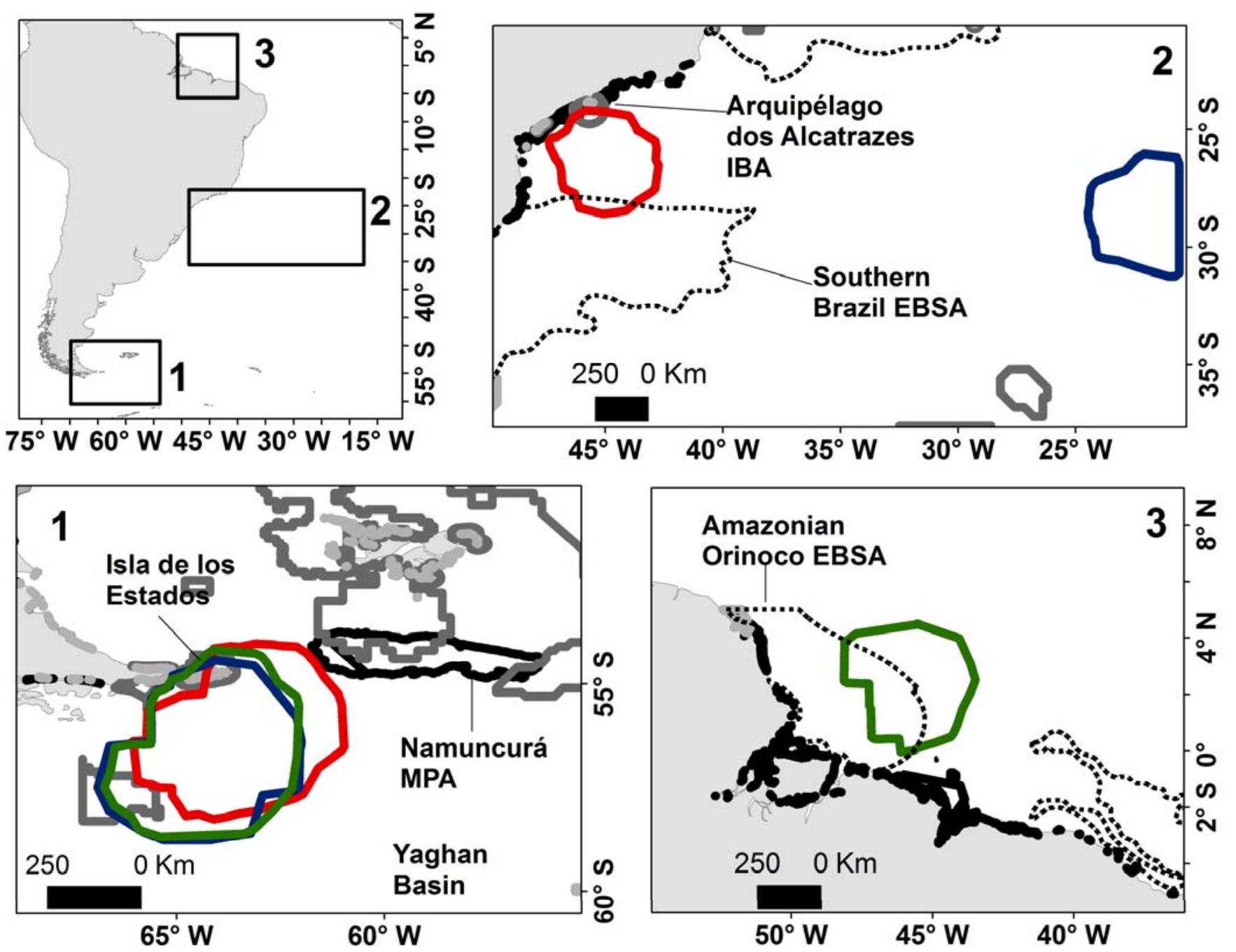


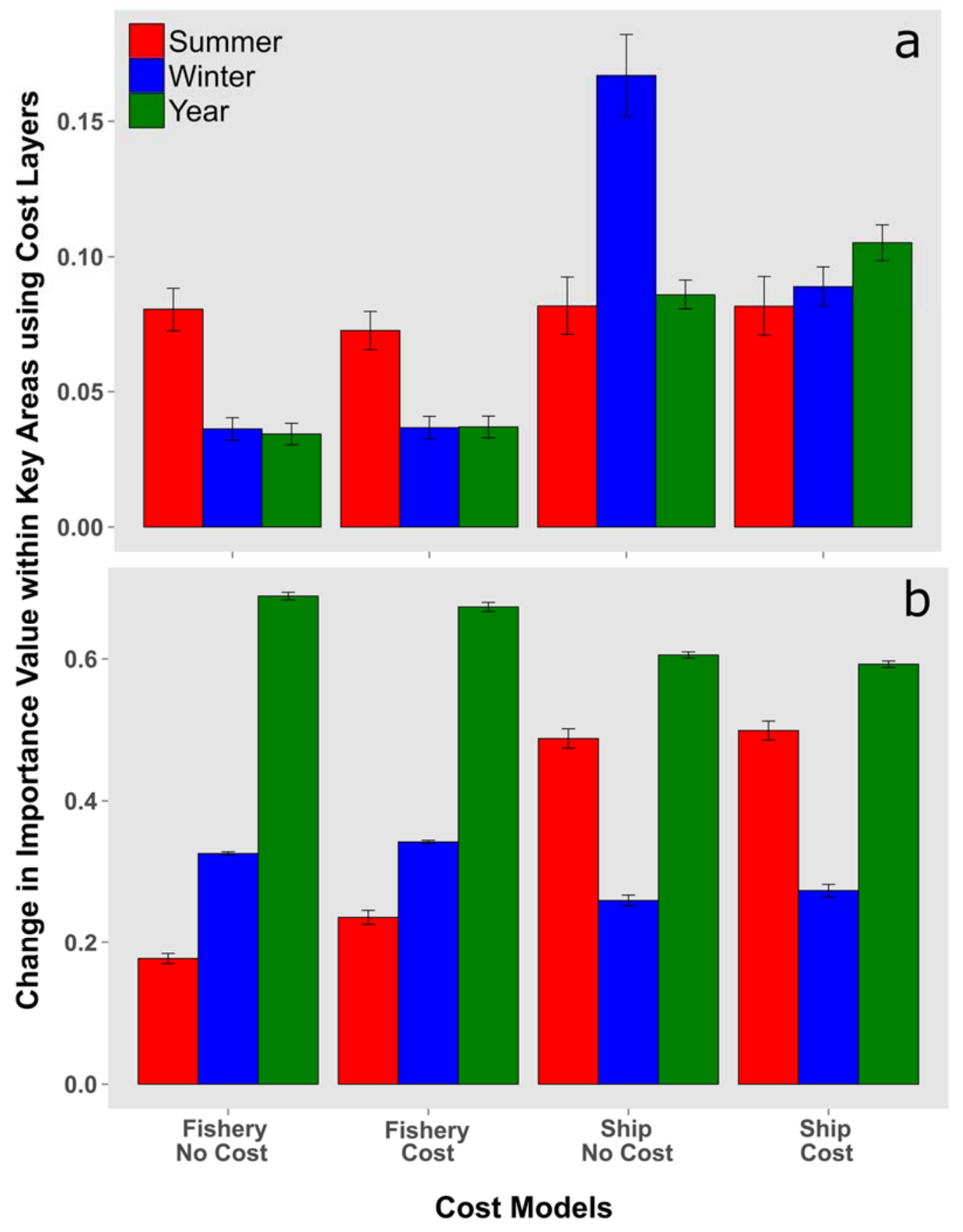


Electronic Supplementary Material for Animal Conservation research article:

Identification of candidate pelagic marine protected areas through a seabird seasonal-, multispecific- and extinction risk-based approach

Krüger $\mathrm{L}^{1,8 *}$, Ramos $\mathrm{JA}^{1}$, Xavier $\mathrm{JC}^{1,2}$, Grémillet $\mathrm{D}^{3,10}$, González-Solís $\mathrm{J}^{4}$, Kolbeinsson $\mathrm{Y}^{5}$, Militão $\mathrm{T}^{4}$, Navarro $\mathrm{J}^{3,6}$, Petry $\mathrm{MV}^{7,8}$, Phillips $\mathrm{RA}^{2}$, Ramírez I ${ }^{9}$, Reyes-González $\mathrm{JM}^{4}$, Ryan $\mathrm{PG}^{10}$, Sigurðsson $\mathrm{IA}^{11}$, Van Sebille $\mathrm{E}^{12}$, Wanless $\mathrm{RM}^{10,13}$, Paiva $\mathrm{VH}^{1}$.

${ }^{1}$ MARE - Marine and Environmental Science Centre, Department of Life Sciences, University of Coimbra, 3000-456 Coimbra, Portugal.

${ }^{2}$ British Antarctic Survey, Natural Environment Research Council, Cambridge UK.

${ }^{3}$ Centre d'EcologieFonctionnelle et Evolutive, UMR 5175, CNRS - Université de Montpellier Université Paul-Valéry Montpellier - EPHE, Montpellier, France.

${ }^{4}$ Department of Animal Biology and Biodiversity Research Institute (IRBio), Faculty of Biology, University of Barcelona, Spain.

${ }^{5}$ Northeast Iceland Nature Research Centre, Húsavík, Iceland.

${ }^{6}$ Conservation Biology Department, Estación Biológica de Doñana, Sevilla, Spain.

${ }^{7}$ Laboratório de Ornitologia e Animais Marinhos, Universidade do Vale do Rio dos Sinos, São Leopoldo, Brasil.

${ }^{8}$ Instituto Nacional de Ciência e Tecnologia Antártico de Pesquisas Ambientais INCT-APA, Brasil.

${ }^{9} \mathrm{Head}$ of Conservation for Europe and Central Asia, Birdlife International.

${ }^{10}$ Percy FitzPatrick Institute of African Ornithology, DST-NRF Centre of Excellence, University of Cape Town, Rondebosch, South Africa.

${ }^{11}$ South Iceland Nature Centre, Vestmannaeyjar, Iceland.

${ }^{12}$ Grantham Institute \& Department of Physics, Imperial College London, United Kingdom.

${ }^{13}$ Seabird Conservation Programme, BirdLife South Africa, Private Bag X5000, 2121, Johannesburg, South Africa

*Corresponding author:

Marine and Environmental Science Centre MARE, rua da Matemática, 49, Coimbra, Portugal, 3000-214

biokruger@gmail.com 

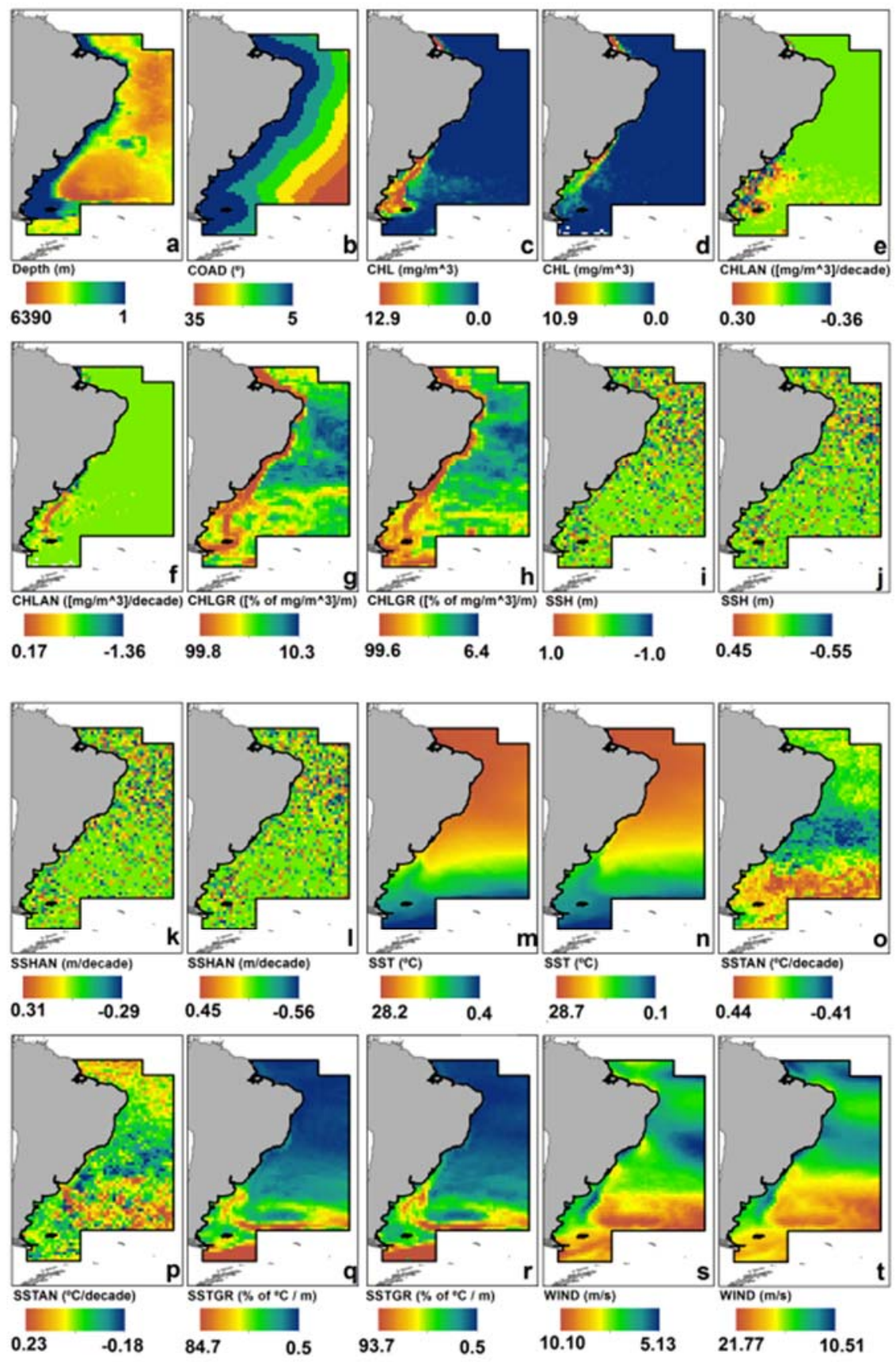

Figure S1 Environmental variables used for the Species Distribution Modelling: (a) depth in meters; (b) Distance to coast (COAD) in degrees; chlorophyll-a concentration (CHL) in $\mathrm{mg} / \mathrm{m}^{3}$, during (c) summer and (d) winter; chlorophyll-a concentration anomaly CHLAN in decade variability of $\mathrm{mg} \mathrm{m}^{-3}$, during (e) summer and (f) winter; CHL gradient (CHLGR) in percentage of $\mathrm{mgm}^{-3}$ variation per meter during $(\mathrm{g})$ summer and $(\mathrm{h})$ winter; sea surface height SSH in meters during (i) summer and (j) winter; sea surface height anomaly (SSHAN) in variability of meters per decade during (k) summer and (l) winter; sea surface temperature SST in ${ }^{\circ} \mathrm{C}$ during (m) summer and (n) winter; sea surface temperature anomaly (SSTAN) in variability of ${ }^{\circ} \mathrm{C}$ per decade during (o) summer and (p) winter; sea surface temperature gradients in percentage of ${ }^{\circ} \mathrm{C}$ change per meter during (q) summer and (r) winter; wind speed in meters per second during ( $\mathrm{s}$ ) summer and $(t)$ winter. Year variables were the average of both summer and winter. 
SI Sensitivity analysis of the Zonation outputs when using different weighting values

The aim of this section is to provide an analysis of the method we used to weight species distribution by the IUCN conservation status, and the habitat connectivity response (in Zonation software called as Boundary-Quality Penalty Curves BQPCs). We used the full weight method that is in the main text to give value to the year-round distribution of all species.

Full model: Each species was weighted by its IUCN conservation status as follows, least concern $(\mathrm{LC})=1$; near threatened $(\mathrm{NT})=2$; vulnerable $(\mathrm{VU})=3$; endangered $(\mathrm{EN})=4$ and critically endangered $(\mathrm{CR})=5$. Boundary Quality Penalty Curves, which are measures of species responses to habitat connection, were constructed empirically based on the IUCN conservation status. We generated linear responses with changing slopes for $\mathrm{CR}=-0.01, \mathrm{EN}=-$ $0.008, \mathrm{VU}=-0.004, \mathrm{NT}=-0.002 \mathrm{LC}=0.0$.

We also generated three other different weight methods: a null model where the weight given for all species is the same (1) and the response to habitat connection $\left(\beta^{\mathrm{h}}\right)$ is constant; a model where LC weights 1 with $\beta^{\mathrm{h}}$ constant and the other levels (NT, VU, EN, CR) weights 2 with $\beta^{\mathrm{h}}=-0.002$ (weight model \#1), a model where LC weights 1 with $\beta^{\mathrm{h}}$ constant, NT weights 2 with $\beta^{\mathrm{h}}=-0.002$, and other levels (VU, EN, CR) weight 3 with $\beta^{\mathrm{h}}=-0.004$ (weight model \#2). Then we tested via simple regression how these three methods are similar to the full model and tested how the probability of species occurrence is related to those weighting outputs through cubic regression.

We found that a null model with equal weight and no $\beta^{\mathrm{h}}$ variation means that the software will give more value to pixels isolated from the edges of the study area, without being realistic nor reflecting any oceanographic process intrinsic to the species distribution, but probably embracing the edges of most species distribution (Fig. S5). It means that high values in this case were concentrated in the middle of the study area (Fig. S5) and were completely opposed to the output we proposed $\left(\mathrm{F}_{1,1652}=3.29, \beta=-0.14, \mathrm{P}=0.07\right)$. On the other hand, one single differentiation on the weights in two $\left(\mathrm{F}_{1,1652}=31.18, \beta=0.18, \mathrm{P}<0.001\right)$ and three $\left(\mathrm{F}_{1,1652}\right.$ $=1556.6, \beta=0.8, \mathrm{P}<0.001)$ groups was enough to approximate the values to the full model output (Fig. S6). The null model weakly reflected the overall distribution of species $\left(\mathrm{R}^{2}=0.04\right.$, $\left.\mathrm{F}_{1,1652}=24.55, \mathrm{P}=0.09\right)$, while the other weight models $\# 1\left(\mathrm{R}^{2}=0.53, \mathrm{~F}_{1,1652}=613.6, \mathrm{P}<0.001\right)$, $\# 2\left(R^{2}=0.63, F_{1,1652}=952.2, P<0.001\right)$ and the full model $\left(R^{2}=0.69, F_{1,1652}=1238.0, P<0.001\right)$ did significantly explained the species distribution (Fig. S7). 

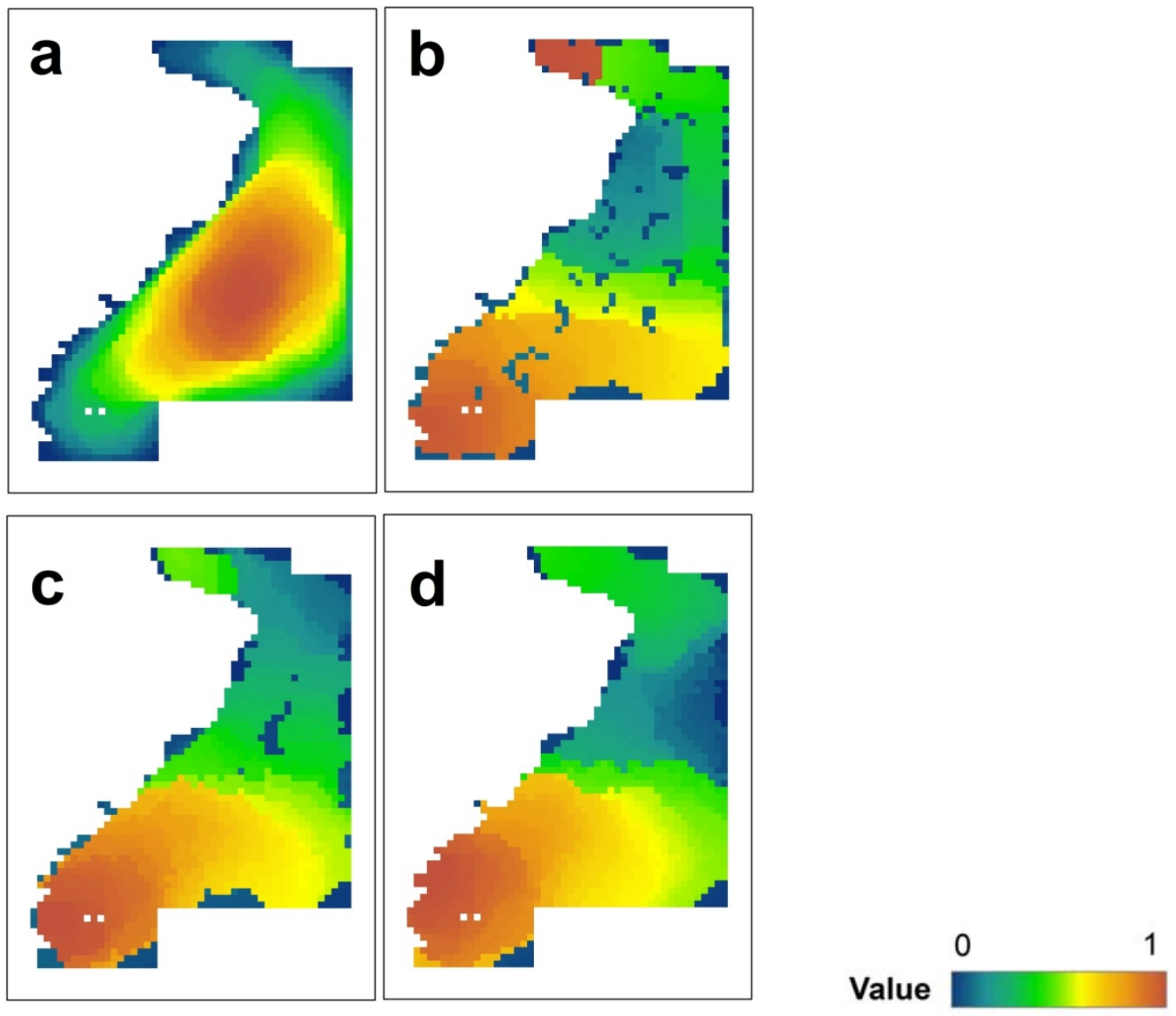

Figure S2 Zonation output showing the how much the values attributed to each pixel change by the weighting method used in building the (a) null model, (b) weight model \#1, (c) weight model \#2 and (d) the full model.

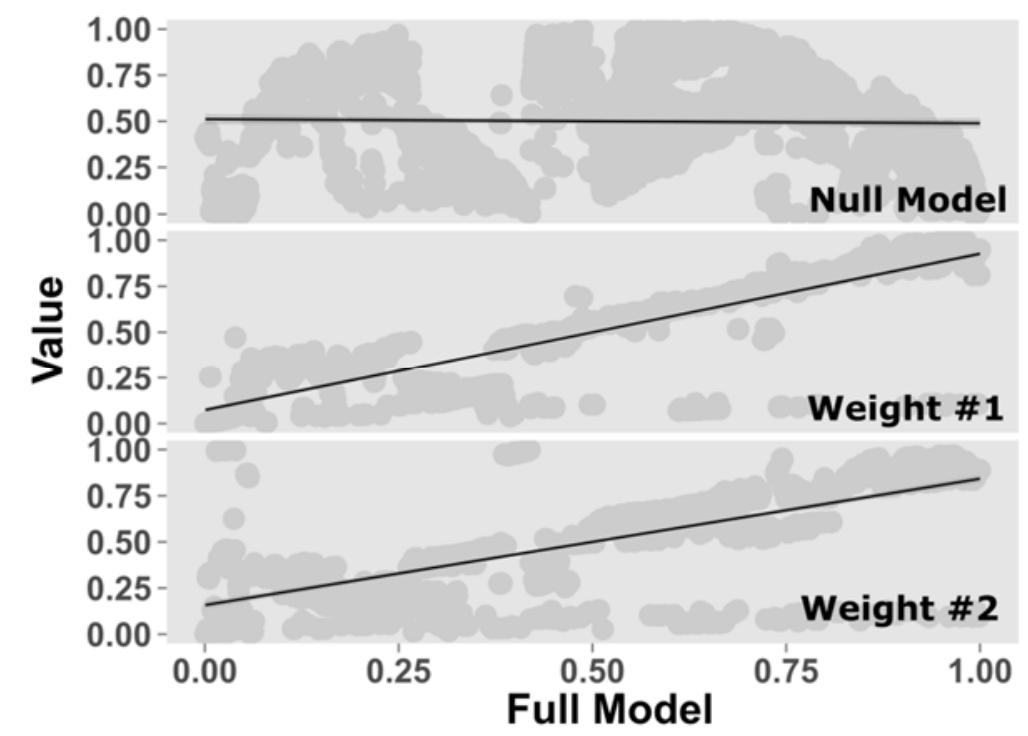

Figure S3 Regression between the full model and the new weight models. Lines are linear trends \pm SE. 

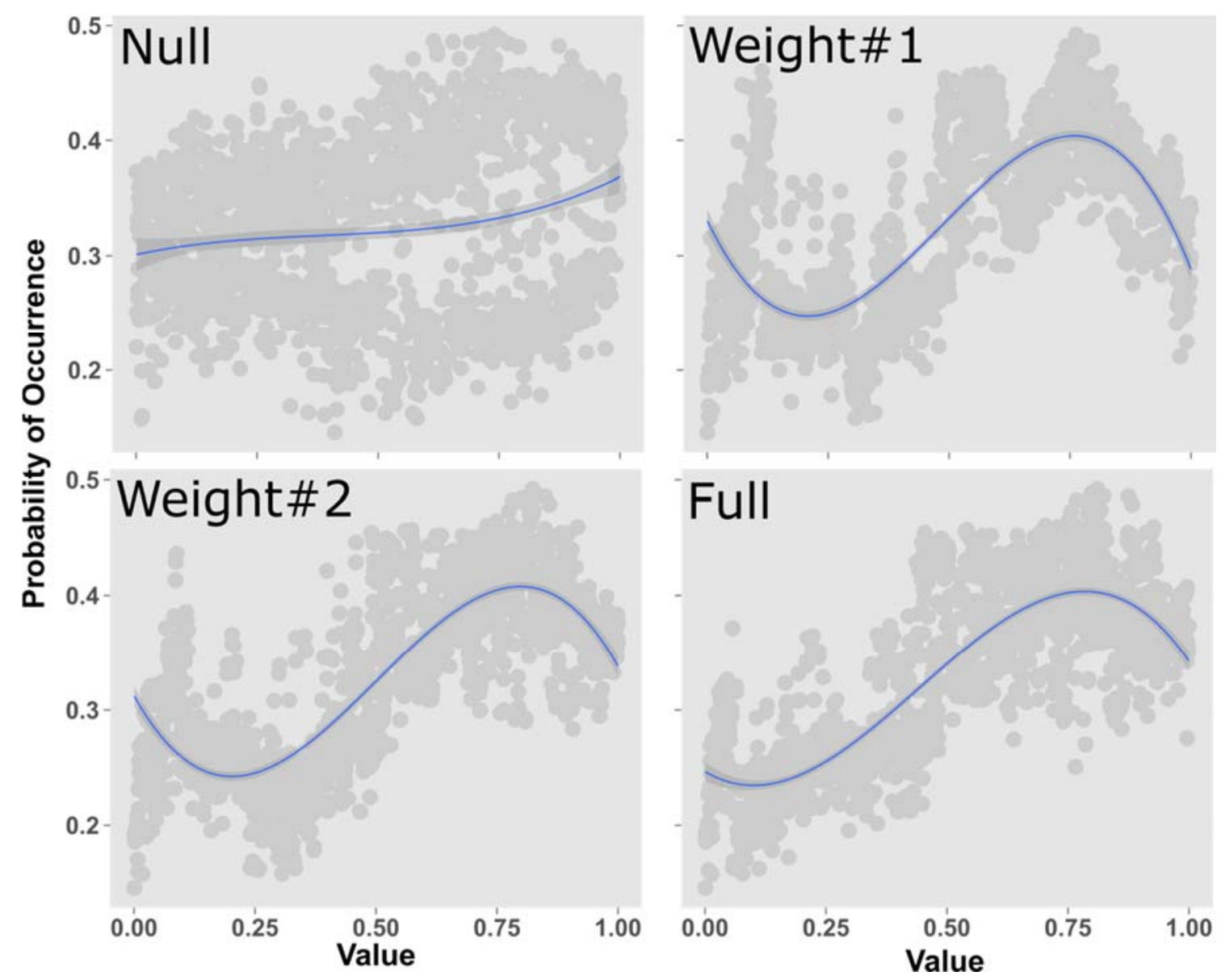

Figure S4 Relation between the overall species probability of occurrence and zonation value for each of the four models. Lines are cubic trend \pm SE. 
SII Mehods for calculating environmental threat variables.

A total of five threat variable were used: ocean surface acidification, oil pollution risk, plastic accumulation, ship density and fishing intensity (Fig. S8). All environmental variables were standardized to have a mean of 0 and an SD of 1 due to differing ranges of variables. Such standardization was executed by dividing each absolute value by the respective maximal value of the environmental variable (Zuur, Ieno \& Smith, 2007).

Ocean surface acidification was measured in terms of normalized changes in aragonite saturation state between pre-industrial and modern times, which is a compound that enhances when Ph decreases (Halpern et al., 2008). The acidification image was generated by Halpern et al.(2008), and we are using it as it is in the publication.

For risk of oil pollution we used the areas of oil accumulation proposed by Halpern et al.(2008). A Nearest Natural Neighbor Interpolation was used to calculate a risk based on the distance from these pollution areas, being the cells presented by Halpern et al.(2008) with value 1.0 , and decreasing according to the distance.

Plastic accumulation was estimated using a dynamic particle flotation model based on movement of buoys (van Sebille, England \& Froyland, 2012; van Sebille et al., 2015; van Sebille, 2014). The model takes in account the coastal population density as a proxy for source of pollution, and predicts the probability of the movements of those particles due to ocean currents for each two month periods along a $1^{\circ} \mathrm{x} 1^{\circ}$ spatial grid. As there are different outputs if we use different periods of the year as the start of the modeling, we run models for all the two month periods along ten years. Each 2 month period output images were used to calculate an average image. This means that for cells with higher values there is a greater probability of plastic accumulation accounting for all possible scenarios. Thus the final images accounted also for the movement of the particles instead of only the final destination of the particles at the end of the 10-year period. We also considered a model with a constant particle release and a single release in time, to make the model more realistic, and calculated a mean of both.

Ship density was computed from the ship density shapefiles made available by the PASTA-MARE project (LuxSpace, 2010) which takes in account three month Satellite Automatic Identification System S-AIS movement of 62000 vessels on a global scale. The technical report (LuxSpace, 2010) shows a similarity between their results and two longer term data bank of the Voluntary Observing Ship from the World Meteorological Organization WMO-VOS (Halpern et al., 2008) which uses one year data of 3374 commercial and research vessels, and Automated Mutual-assistance Vessel Rescue system AMVER that uses 3809 commercial vessels. We believe that the PASTA-MARE project is more accurate in terms of characterizing the ship density per area in relative terms because it uses all the available data for 
any type and flag of vessels, while the more long-term data for VOS and AMVER are probably biased for the more representative types of vessels. We correlated the Halpern et al. (2008) with the PASTA-MARE results using a spatial correlation analysis on Spatial Analysis in Macroecology SAM software (Rangel, Diniz-Filho \& Bini, 2010), and found a significant adjustment between both $(\mathrm{R}=0.61, \mathrm{~F}=28.8, \mathrm{P}<0.001)$ meaning that the short term data from PASTA-MARE is a fair approximation for a year-long data bank. Fishing intensity was measured as the fishing vessel density from the PASTA-MARE data (LuxSpace, 2010).

References

Halpern, B.S., Walbridge, S., Selkoe, K. a, Kappel, C. V, Micheli, F., D’Agrosa, C., Bruno, J.F., Casey, K.S., Ebert, C., Fox, H.E., Fujita, R., Heinemann, D., Lenihan, H.S., Madin, E.M.P., Perry, M.T., Selig, E.R., Spalding, M., Steneck, R. \& Watson, R. (2008). A global map of human impact on marine ecosystems. Science 319, 948-52.

LuxSpace. (2010). Preparatory action for assessment of the capacity of spaceborne automatic identification system receivers to support EU maritime policy. Tech. Note 4 1, 1-32.

Rangel, T.F., Diniz-Filho, J.A.F. \& Bini, L.M. (2010). SAM: a comprehensive application for Spatial Analysis in Macroecology. Ecography 33, 46-50.

Van Sebille, E. (2014). Adrift.org.au - A free, quick and easy tool to quantitatively study planktonic surface drift in the global ocean. J. Exp. Mar. Bio. Ecol. 461, 317-322.

Van Sebille, E., England, M.H. \& Froyland, G. (2012). Origin, dynamics and evolution of ocean garbage patches from observed surface drifters. Environ. Res. Lett. 7, 044040.

Van Sebille, E., Wilcox, C., Lebreton, L., Maximenko, N., Hardesty, B.D., van Franeker, J.A., Eriksen, M., Siegel, D., Galgani, F. \& Law, K.L. (2015). A global inventory of small floating plastic debris. Environ. Res. Lett. 10, 124006.

Zuur, A.F., Ieno, E.N. \& Smith, G.M. (2007). Analysing Ecological Data. New York, NY: Springer. 


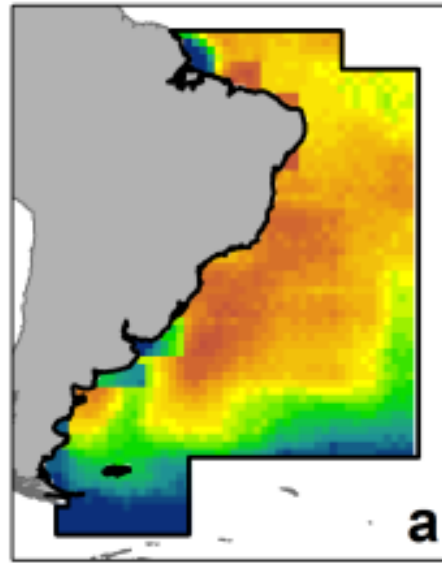

ACID

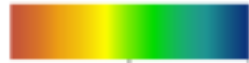

0.93

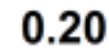

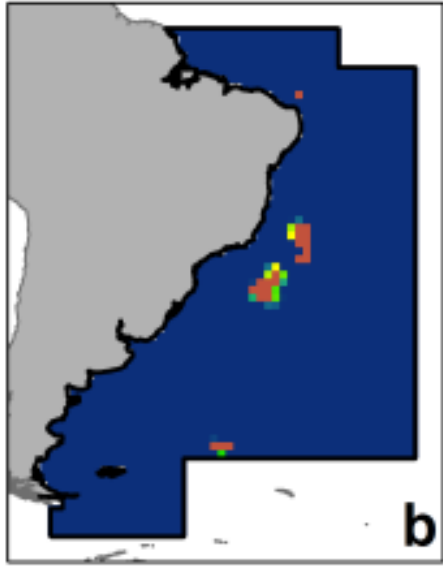

OIL

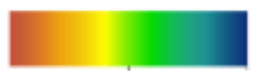

1.00
0.00

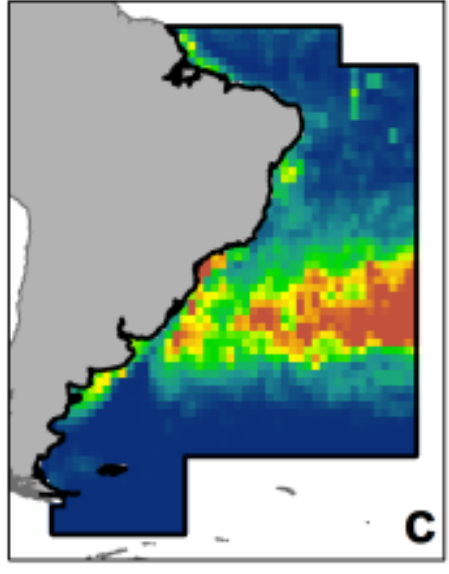

PLASTIC

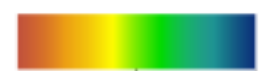

1.00

0.00

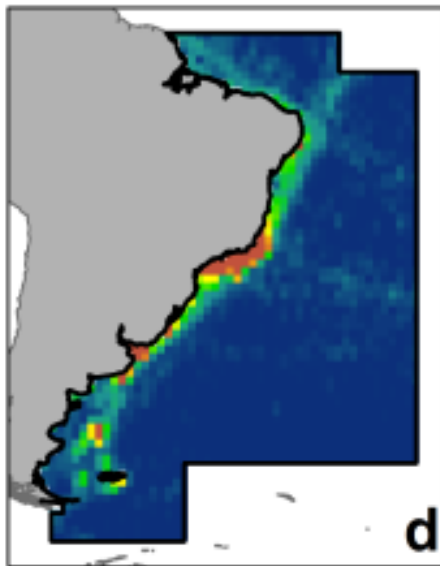

SHIP

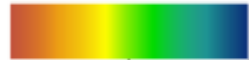

107

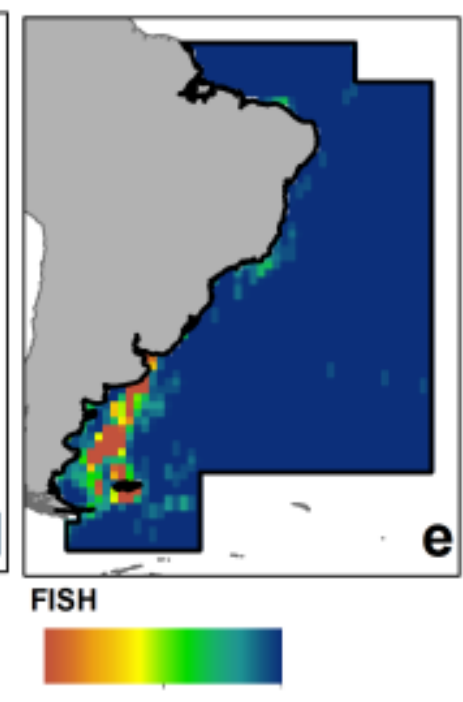

20
0

Figure S5 Environmental change variables: (a) ocean surface acidification (ACID) measured in terms of normalized changes in aragonite saturation state between pre-industrial and modern times (see Halpern et al 2008); (b) Risk of oil pollution (OIL) measured as a distance probability given the known points of oil spills or oil platforms from Halpern et al (2008) as value 1; (c) 10-year mean percentage of plastic pollution (PLASTIC) based on the particle drift model (Van Sebille et al 2012 2015); (d) ship density (SHIP) as the average abundance of vessels per grid cell (LuxSpace 2010); (e) fishing intensity (FISH) is a measure of density of fishing vessels. 
Table S1 Loadings from the PCA. The values represent the proportion of each variable that is explained by each of the PCA axis, and the signal (- or + ) indicates the relation of the variables with the axes. Variables with higher correlation on the same axis are not independent from each other, meaning that they vary together. Table presents results from the axis whose eigenvalues were above 1.0. Higher values for each variable by season are presented in bold. Chlorophyll (CHL), CHL anomaly (CHLAN), CHL gradient (CHLGR), coast distance (COAD), Depth (DEPTH), Sea Surface Height (SSH), SSH anomaly (SSHAN), Sea Surface Temperature (SST), SST anomaly (SSTAN), SST gradient (SSTGR), wind speed (WIND).

\begin{tabular}{lcccccccccccc}
\hline \multirow{2}{*}{ Variables } & \multicolumn{4}{c}{ Summer } & \multicolumn{1}{c}{ Winter } & \multicolumn{4}{c}{ Year } \\
& AX1 & AX2 & AX3 & AX4 & AX1 & AX2 & AX3 & AX4 & AX1 & AX2 & AX3 & AX4 \\
\hline CHL & 0.12 & $\mathbf{- 0 . 6 4}$ & 0.10 & -0.17 & -0.03 & $\mathbf{0 . 6 0}$ & 0.00 & 0.57 & 0.01 & $\mathbf{- 0 . 6 5}$ & -0.06 & -0.48 \\
CHLAN & 0.11 & 0.05 & 0.01 & $\mathbf{- 0 . 9 8}$ & 0.09 & -0.21 & 0.04 & $\mathbf{- 0 . 7 7}$ & 0.12 & 0.22 & 0.01 & $\mathbf{0 . 8 5}$ \\
CHLGR & 0.43 & $\mathbf{- 0 . 7 0}$ & 0.07 & -0.01 & 0.57 & $\mathbf{0 . 6 7}$ & 0.06 & -0.07 & 0.46 & $\mathbf{- 0 . 7 4}$ & -0.03 & 0.15 \\
COAD & 0.24 & $\mathbf{0 . 7 2}$ & -0.03 & 0.02 & 0.25 & $\mathbf{- 0 . 7 3}$ & -0.10 & 0.34 & 0.31 & $\mathbf{0 . 7 0}$ & 0.03 & -0.35 \\
DEPTH & -0.13 & $\mathbf{0 . 8 7}$ & -0.07 & -0.08 & -0.17 & $\mathbf{- 0 . 8 3}$ & -0.08 & 0.11 & -0.08 & $\mathbf{0 . 8 6}$ & 0.04 & -0.11 \\
SSH & -0.03 & 0.09 & $\mathbf{0 . 9 9}$ & 0.01 & -0.01 & -0.09 & $\mathbf{0 . 9 9}$ & 0.05 & -0.01 & 0.06 & $\mathbf{- 0 . 9 5}$ & 0.00 \\
SSHAN & -0.04 & 0.10 & $\mathbf{0 . 9 9}$ & 0.01 & -0.01 & -0.10 & $\mathbf{0 . 9 9}$ & 0.05 & -0.01 & 0.07 & $\mathbf{- 0 . 9 5}$ & 0.03 \\
SST & $\mathbf{0 . 9 4}$ & -0.03 & -0.01 & -0.08 & $\mathbf{- 0 . 9 4}$ & 0.00 & -0.02 & 0.05 & $\mathbf{- 0 . 9 3}$ & 0.06 & 0.00 & -0.02 \\
SSTAN & $\mathbf{0 . 7 5}$ & 0.16 & 0.01 & -0.04 & 0.26 & -0.16 & -0.06 & $\mathbf{0 . 4 2}$ & $\mathbf{0 . 7 2}$ & 0.12 & -0.03 & -0.11 \\
SSTGR & $\mathbf{0 . 8 4}$ & -0.03 & 0.00 & 0.09 & $\mathbf{0 . 8 5}$ & 0.08 & 0.01 & -0.10 & $\mathbf{0 . 8 3}$ & -0.12 & 0.01 & 0.09 \\
WIND & $\mathbf{0 . 8 3}$ & 0.23 & 0.00 & 0.00 & $\mathbf{0 . 7 8}$ & -0.41 & -0.03 & 0.10 & $\mathbf{0 . 8 2}$ & 0.29 & 0.01 & -0.10 \\
\hline
\end{tabular}




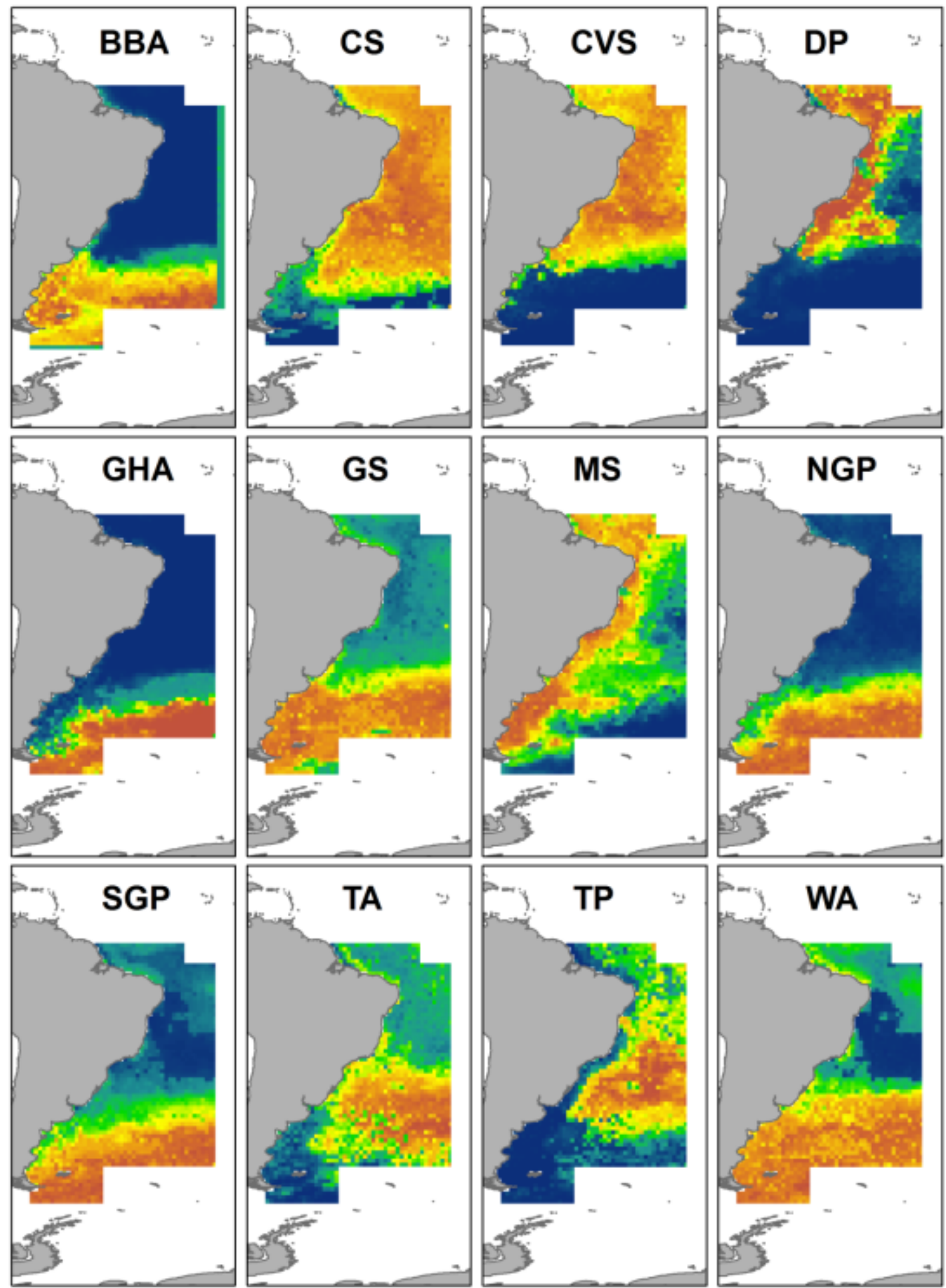

Figure S6 Summer probability of occurrence of Black-browed Albatross (BBA), Cory's Shearwater (CS), Cape Verde Shearwater (CVS), Deserta's Petrel (DP), Grey-headed Albatross (GHA), Great Shearwater (GS), Manx Shearwater (MS), Northern Giant Petrel (NGP), Southern Giant Petrel (SGP), Tristan Albatross (TA), Trindade Petrel (TP), Wandering Albatross (WA), as estimated by MaxEnt models. Probability varies from 0 (dark blue) to 1 (dark red). 

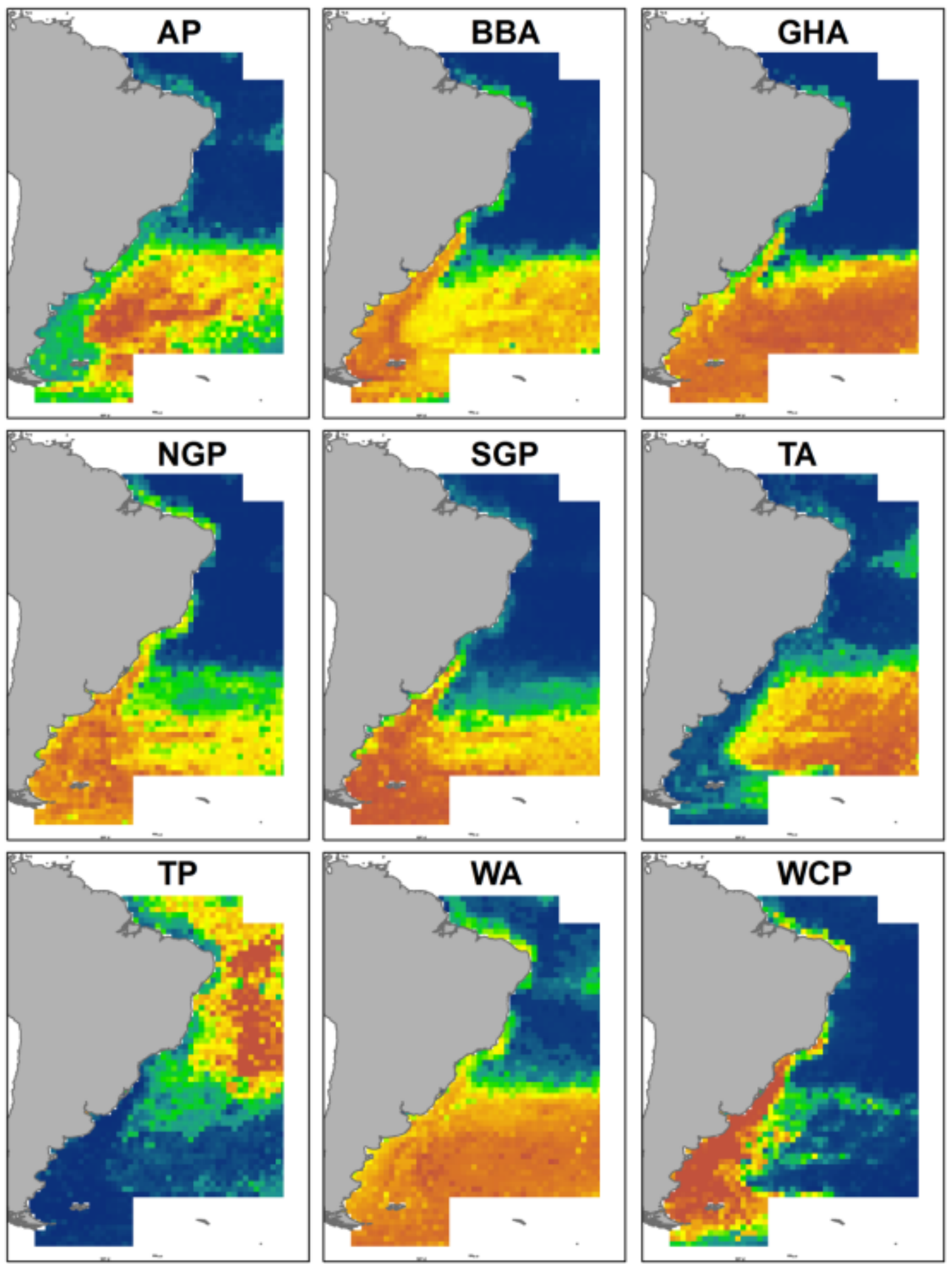

Figure S7 Winter probability of occurrence of Antarctic Prion (AP), Black-browed Albatross (BBA), Grey-headed Albatross (GHA), Northern Giant Petrel (NGP), Southern Giant Petrel (SGP), Tristan Albatross (TA), Trindade Petrel (TP), Wandering Albatross (WA), Whitechinned Petrel (WCP), as estimated by MaxEnt models.Probability varies from 0 (dark blue) to 1 (dark red). 

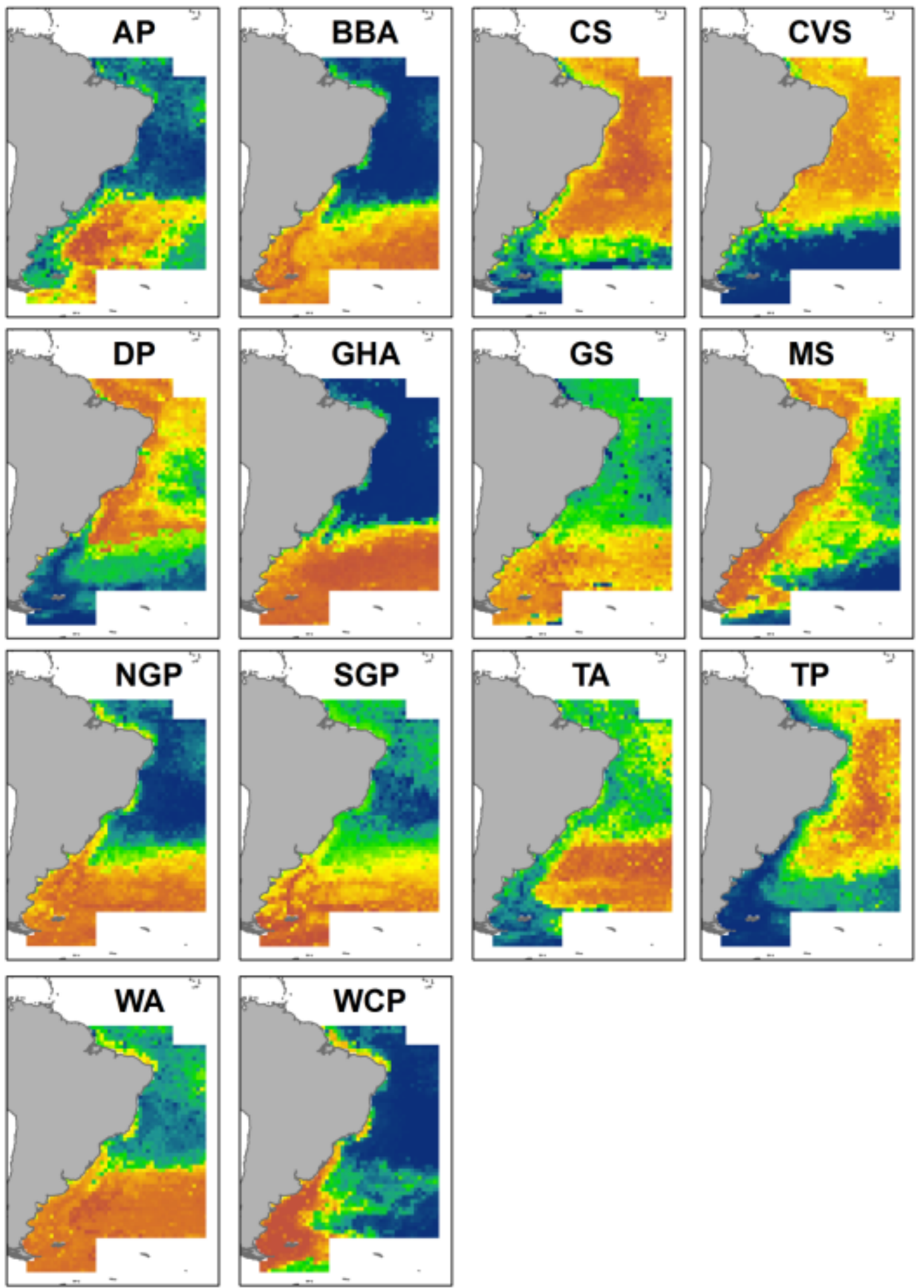

Figure S8 Year-round probability of occurrence of Antarctic Prion (AP), Black-browed Albatross (BBA), Cory's Shearwater (CS), Cape Verde Shearwater (CVS), Deserta's Petrel (DP), Grey-headed Albatross (GHA), Great Shearwater (GS), Manx Shearwater (MS), Northern Giant Petrel (NGP), Southern Giant Petrel (SGP), Tristan Albatross (TA), Trindade Petrel (TP), Wandering Albatross (WA), White-chinned Petrel (WCP), as estimated by MaxEnt models. Probability varies from 0 (dark blue) to 1 (dark red). 


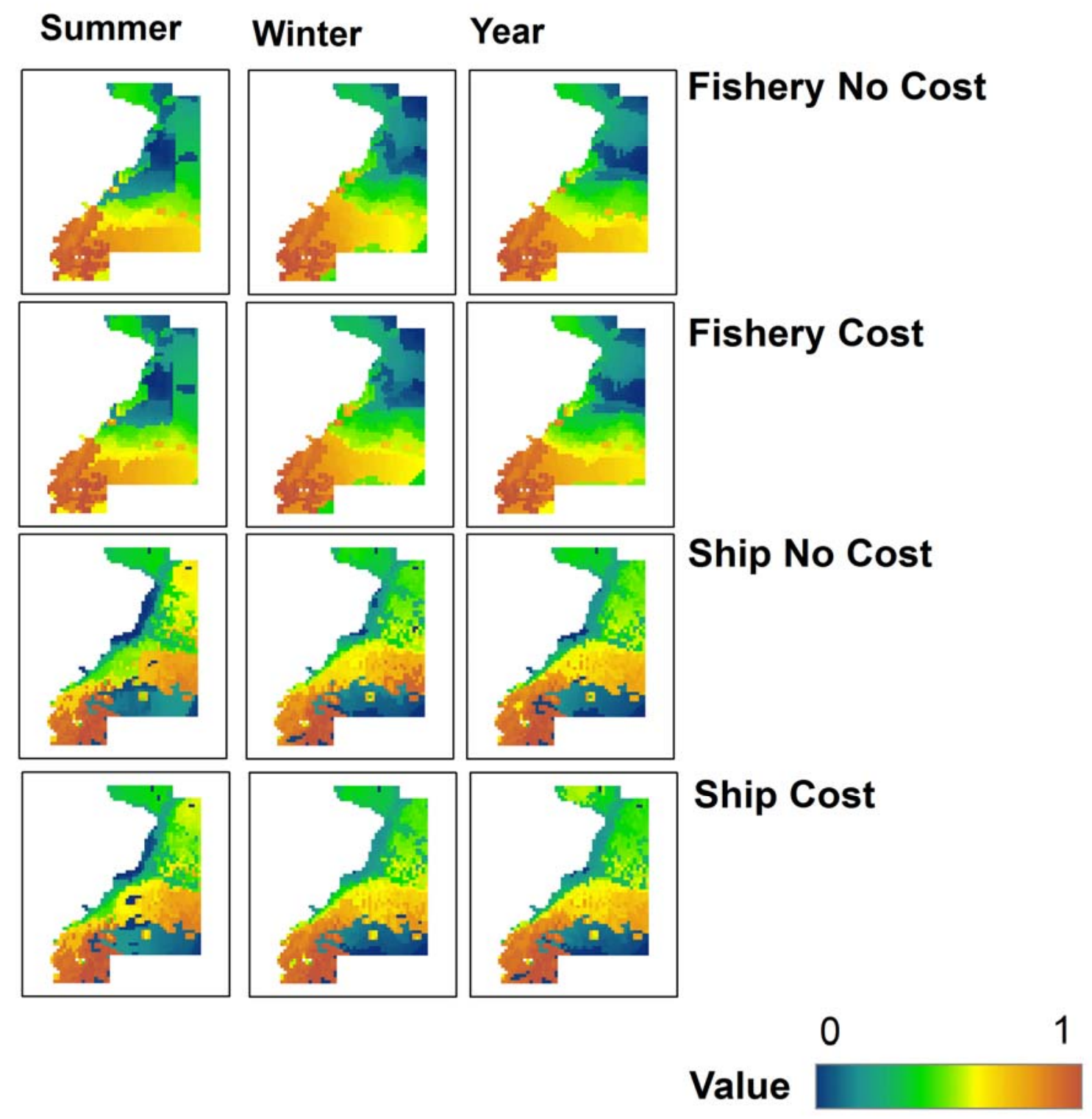

Figure S9 Zonation value for the different cost models, for southern seabirds. 


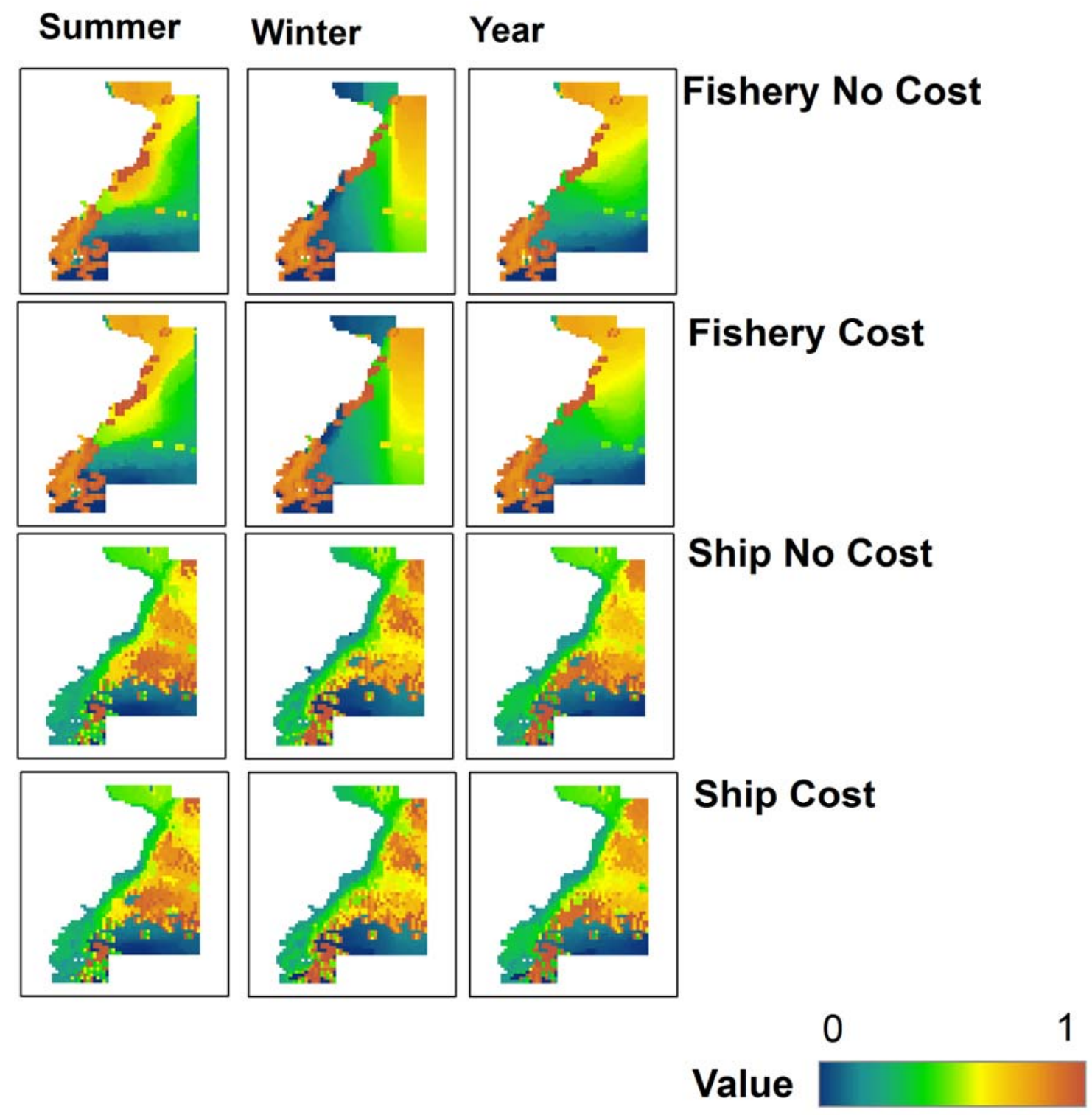

Figure S10 Zonation value for the different cost models models, for northern seabirds. 
Table S2 Generalized Linear Mixed Model results comparing change in values for the proposed key marine areas between seabird assemblages (Southern and Northern) and time-frames (summer, winter, year) when using different cost models (no cost and cost for Fishing Density and Ship Density).

\begin{tabular}{|c|c|c|c|}
\hline Models & $\beta$ & SE & $\mathrm{t}$ \\
\hline (Intercept) & 0.0913 & 0.0142 & 6.44 \\
\hline Assemblage:Northern & 0.0966 & 0.0113 & 8.58 \\
\hline Time-Frame:Winter & -0.0441 & 0.0113 & -3.92 \\
\hline Time-Frame:Year & -0.0460 & 0.0113 & -4.09 \\
\hline Cost-Model:Fishery Cost & -0.0078 & 0.0113 & -0.7 \\
\hline Cost-Model:Ship No Cost & 0.0015 & 0.0113 & 0.13 \\
\hline Cost-Model:Ship Cost & 0.0014 & 0.0113 & 0.13 \\
\hline Assemblage:Northern* Time-Frame:Winter & 0.1936 & 0.0162 & 11.93 \\
\hline Assemblage:Northern:* Time-Frame:Year & 0.5585 & 0.0159 & 35.06 \\
\hline Assemblage:Northern* Cost-Model:Fishery Cost & 0.0667 & 0.0159 & 4.19 \\
\hline Assemblage:Northern* Cost-Model:Ship No Cost & 0.3094 & 0.0159 & 19.42 \\
\hline Assemblage:Northern* Cost-Model:Ship Cost & 0.3206 & 0.0159 & 20.13 \\
\hline Time-Frame:Winter* Cost-Model:Fishery Cost & 0.0083 & 0.0159 & 0.52 \\
\hline Time-Frame:Year* Cost-Model:Fishery Cost & 0.0105 & 0.0159 & 0.66 \\
\hline Time-Frame:Winter* Cost-Model:Ship No Cost & 0.1292 & 0.0159 & 8.11 \\
\hline Time-Frame:Year* Cost-Model:Ship No Cost & 0.0502 & 0.0159 & 3.15 \\
\hline Time-Frame:Winter* Cost-Model:Ship Cost & 0.0513 & 0.0159 & 3.22 \\
\hline Time-Frame:Year* Cost-Model:Ship Cost & 0.0694 & 0.0159 & 4.36 \\
\hline Assemblage:Northern* Time-Frame:Winter* Cost-Model:Fishery Cost & -0.0509 & 0.0229 & -2.22 \\
\hline Assemblage:Northern* Time-Frame:Year* Cost-Model:Fishery Cost & -0.0847 & 0.0225 & -3.76 \\
\hline Assemblage:Northern* Time-Frame:Winter* Cost-Model:Ship No Cost & -0.5062 & 0.0229 & -22.07 \\
\hline Assemblage:Northern* Time-Frame:Year* Cost-Model:Ship No Cost & -0.4450 & 0.0225 & -19.76 \\
\hline Assemblage:Northern* Time-Frame:Winter* Cost-Model:Ship Cost & -0.4255 & 0.0229 & -18.55 \\
\hline Assemblage:Northern* Time-Frame:Year* Cost-Model:Ship Cost & -0.4885 & 0.0225 & -21.69 \\
\hline
\end{tabular}

